\title{
Vinylation of Aryl Bromides Using an Inexpensive Vinylpolysiloxane
}

\author{
Scott E. Denmark* and Christopher R. Butler \\ Department of Chemistry, University of Illinois Urbana-Champaign, Illinois 61801
}

\section{SUPPORTING INFORMATION}

\section{Table of Contents}

Page

General Experimental $\quad S 1$

Response Factors $\quad S 4$

Literature Preparations $\quad S 4$

$\begin{array}{ll}\text { Experimental Procedures } & S 5\end{array}$

$\begin{array}{ll}\text { References } & \text { S29 }\end{array}$

${ }^{1} \mathrm{H}$ NMR Spectra $\quad S 30$

\section{General Experimental}

All reactions were performed in oven-dried $\left(140^{\circ} \mathrm{C}\right)$ or flame dried glassware under an atmosphere of dry nitrogen or argon, unless noted. Reaction solvents tetrahydrofuran (Fisher, HPLC grade), diethyl ether (Fisher, BHT stabilized ACS grade) and methylene chloride (Fisher, unstabilized HPLC grade) were dried by percolation through two columns packed with neutral alumina under a positive pressure of argon. Reaction solvents hexane (Fisher, OPTIMA grade) and toluene (Fisher, ACS grade) were dried by percolation through a column packed with neutral alumina and a column packed with Q5 reactant, a supported copper catalyst for scavenging oxygen, under a positive pressure of argon. Reaction solvent acetonitrile (Fisher, HPLC grade) was used without further purification. DME and dioxane were distilled from $\mathrm{Na}$ and benzophenone. Solvents for filtration and chromatography were certified ACS grade. Commercial reagents were purified by distillation or recrystallization prior to use. "Brine" refers to a saturated solution of sodium chloride. All reaction temperatures correspond to internal temperatures measured with Teflon coated thermocouples.

${ }^{1} \mathrm{H}$ NMR spectra and ${ }^{13} \mathrm{C}$ NMR spectra were recorded on either a Varian Unity 400 (400 $\left.\mathrm{MHz},{ }^{1} \mathrm{H} ; 100 \mathrm{MHz},{ }^{13} \mathrm{C}\right)$ or a Varian Unity $500\left(500 \mathrm{MHz},{ }^{1} \mathrm{H} ; 125 \mathrm{MHz},{ }^{13} \mathrm{C}\right)$ spectrometer. 
Spectra were referenced to residual chloroform $\left(7.26 \mathrm{ppm},{ }^{1} \mathrm{H} ; 77.0 \mathrm{ppm},{ }^{13} \mathrm{C}\right)$. Chemical shifts are reported in ppm, multiplicities are indicated by s (singlet), $\mathrm{d}$ (doublet), $\mathrm{t}$ (triplet), q (quartet), $\mathrm{p}$ (pentet), h (hextet), m (multiplet) and br (broad). The prefix nfo (non-first order) coupling when used, indicates coupling which is not first order. Coupling constants, $J$, are reported in Hertz. Analytical thin-layer chromatography was performed on Merck silica gel plates with QF254 indicator. Visualization was accomplished with UV (254), potassium permanganate $\left(\mathrm{KMnO}_{4}\right)$ or iodine $\left(\mathrm{I}_{2}\right)$. Column chromatography was performed using 230-400 mesh silica gel purchased from EM Science.

Electron impact mass spectroscopy (EI) was performed at $70 \mathrm{eV}$. Data are reported in the form of $\mathrm{m} / \mathrm{z}$ (intensity relative to base peak $=100$ ). Infrared spectra (IR) peaks are reported in $\mathrm{cm}^{-1}$ with the indicated relative intensities: s (strong, 67-100 \%); m (medium, 34-66\%); w (weak, 0-33\%). Analytical capillary gas chromatography (GC) was performed using a gas chromatograph fitted with a flame ionization detector $\left(\mathrm{H}_{2}\right.$ carrier gas, $\left.1 \mathrm{~mL} / \mathrm{min}\right)$. GC Method 1: Injections were made onto a Hewlett-Packard HP-5 50-m cross-linked 5\%-phenyl methyl silicone gum phase column. The injector and detector temperature were $250{ }^{\circ} \mathrm{C}$. The column oven temperature was $225{ }^{\circ} \mathrm{C}$, isothermal. Total run time was $8 \mathrm{~min}$. Retention times $\left(t_{R}\right)$ and integrated ratios were obtained from reporting integrators. Melting points (mp) were determined on a Thomas-Hoover capillary melting point apparatus in sealed tubes and are corrected. Bulbto-bulb distillations were performed on a Kugelrohr; boiling points (bp) corresponding to uncorrected air-bath temperatures (ABT).

Palladium acetate (Strem), palladium bromide (Strem), and 2-(di-tbutylphosphino)biphenyl (Strem), and 1,3,5,7-tetramethyl-1,3,5,7-tetravinylcyclotetrasiloxane (Gelest) were used as received. A $1.0 \mathrm{M}$ solution of tetra- $n$-butylammonium fluoride (TBAF) was made from the trihydrate salt purchased from Fluka or Acros, dissolved in dry THF, and stored under argon. 


\section{Response Factors}

Response factors $\left(\mathrm{R}_{\mathrm{f}}\right)$ for quantitative GC analysis for GC Method 1 were obtained by the equation below:

Eq1: Response factor for $\mathrm{A}=($ area $\mathrm{A} *$ mmol biphenyl)/ (mmol A * area biphenyl)

\begin{tabular}{|c|c|c|c|c|}
\hline mmol biphenyl & Area biphenyl & mmol 4-bromoacetophenone & Area 4-bromoacetophenone & Response Factor \\
\hline 0.405 & 141445 & 0.377 & 78319 & 1.68 \\
\hline 0.405 & 93881 & 0.377 & 50428 & 1.73 \\
\hline 0.405 & 217973 & 0.377 & 116391 & 1.74 \\
\hline 0.408 & 1167410 & 0.403 & 651991 & 1.77 \\
\hline 0.408 & 447166 & 0.403 & 252412 & 1.75 \\
\hline 0.408 & 83790 & 0.403 & 45036 & 1.84 \\
\hline 0.406 & 91379 & 0.406 & 54336 & 1.68 \\
\hline 0.406 & 51149 & 0.406 & 29321 & 1.74 \\
\hline \multirow[t]{2}{*}{0.406} & 34374 & 0.406 & 19516 & 1.76 \\
\hline & & & Avg: & 1.74 \\
\hline mmol biphenyl & Area biphenyl & mmol 3a & Area 3a & Response Factor \\
\hline 0.392 & 89274 & 0.403 & 51625 & 1.77 \\
\hline 0.392 & 140561 & 0.403 & 77311 & 1.87 \\
\hline 0.392 & 76845 & 0.403 & 42984 & 1.83 \\
\hline 0.337 & 75137 & 0.406 & 49002 & 1.85 \\
\hline 0.337 & 82876 & 0.406 & 53847 & 1.85 \\
\hline 0.337 & 84735 & 0.406 & 57321 & 1.78 \\
\hline
\end{tabular}

\section{Literature Preparations}

Allylpalladium chloride $\operatorname{dimer}^{1}$, palladium bis(dibenzylideneacetone) ${ }^{2}$, and 4bromoacetamide ${ }^{3}$ were prepared by the literature procedures. 


\section{General Procedure I: Cross-coupling of 4-Bromoacetophenone with 1,3,5,7-Tetramethyl}

\section{1,3,5,7-tetravinylcyclotetrasiloxane:}

To an oven-dried, 5-mL, 2-necked, round-bottom flask equipped with a magnetic stir bar, septum and nitrogen inlet was added biphenyl and the ligand. The flask was then evacuated and refilled with argon, and this evacuation/refill process was repeated two additional times. A solution of 1,3,5,7-tetramethyl-1,3,5,7-tetravinylcyclotetrasiloxane (51.7 mg, $0.15 \mathrm{mmol}, 0.3$ equiv) in THF (0.2 mL), followed by TBAF ( $1 \mathrm{~mL}, 1 \mathrm{M}$ in THF, $1 \mathrm{mmol}, 2.0$ equiv) were then sequentially added to the flask, and the resulting mixture was allowed to stir for 10 min at room temperature. 4-Bromoacetophenone $(99.5 \mathrm{mg}, 0.5 \mathrm{mmol})$ and the palladium source were then added, and the reaction was either allowed to stir at room temperature or was heated to $50{ }^{\circ} \mathrm{C}$. The progress of the reaction was monitored by GC as follows: an aliquot of the reaction mixture was filtered through a small amount to silica gel with EtOAc and was analyzed by GC method 1.

\section{Table 1, entry 1}

Following General Procedure I, palladium dibenzylideneacetone $(9.6 \mathrm{mg}, 0.016 \mathrm{mmol}$, 0.05 equiv), 4-bromoacetophenone (49.8 mg, $0.25 \mathrm{mmol})$, 1,3,5,7-tetramethyl-1,3,5,7tetravinylcyclotetrasiloxane $(35.4 \mathrm{mg}, 0.102 \mathrm{mmol}, 0.4$ equiv), and TBAF $(0.5 \mathrm{~mL}, 1 \mathrm{M}$ in THF, $0.5 \mathrm{mmol}, 2$ equiv) were stirred at room temperature for $18 \mathrm{~h}$. Aliquots of the reaction mixture was analyzed by GC Method 1 at 1 h, 3 h, 6 h, 18 h. 3a, $t_{R} 5.39$ min (was not detected).

\section{Table 1, entry 2}

Following General Procedure I, allyl palladium chloride dimer (4.5 mg, $0.012 \mathrm{mmol}$, 0.075 equiv), 4-bromoacetophenone (49.8 $\mathrm{mg}, 0.249 \mathrm{mmol})$, 1,3,5,7-tetramethyl-1,3,5,7tetravinylcyclotetrasiloxane $(25.8 \mathrm{mg}, 0.75 \mathrm{mmol}, 0.3$ equiv), and TBAF $(0.5 \mathrm{~mL}, 1 \mathrm{M}$ in THF, $0.5 \mathrm{mmol}, 2$ equiv) were stirred at room temperature for $1 \mathrm{~h}$. An aliquot of the reaction mixture was analyzed by GC Method 1. 3a, $t_{R} 5.39 \mathrm{~min}$ (was not detected). 


\section{General Procedure II: Vinylation of Aryl Bromides Using Solvents other than} Tetrahydrofuran

\section{Table 1, entry 3:}

To an oven-dried, 2-necked, 5-mL condenser flask equipped with a magnetic stir bar, condenser, and septum was added TBAF (161 mg, $0.51 \mathrm{mmol}, 2.0$ equiv) in the dry box. Upon removal from the dry box, dioxane $(0.5 \mathrm{~mL})$ was added via syringe, followed by a solution of 1,3,5,7-tetramethyl-1,3,5,7-tetravinylcyclotetrasiloxane (31 $\mathrm{mg}, 0.09 \mathrm{mmol}, 0.32$ equiv) in dioxane $(0.1 \mathrm{~mL})$, and this mixture was allowed to stir for $15 \mathrm{~min}$ at room temperature. 4bromoacetophenone (49.2 mg, $0.25 \mathrm{mmol}$ ) and APC (4.6 mg, $0.012 \mathrm{mmol}, 0.05$ equiv) were then added, and the reaction was stirred at room temperature for $18 \mathrm{~h}$. Aliquots of the reaction mixture was filtered through a small amount to silica gel with EtOAc and was analyzed by GC method 1 at $1 \mathrm{~h}, 3 \mathrm{~h}$, and $18 \mathrm{~h}$. 3a, $t_{R} 5.39 \mathrm{~min}$ (was not detected).

\section{Table 1, entry 4:}

Following General Procedure II, TBAF (157 mg, $0.5 \mathrm{mmol}, 1.9$ equiv), DMF (0.5 mL) 1,3,5,7-tetramethyl-1,3,5,7-tetravinylcyclotetrasiloxane (27 mg, $0.078 \mathrm{mmol}, 0.3 \mathrm{equiv})$, 4bromoacetophenone (52.1 mg, $0.26 \mathrm{mmol}$ ), and APC (4.5 mg, $0.012 \mathrm{mmol}, 0.047$ equiv) were stirred at room temperature for $18 \mathrm{~h}$. An aliquot of the reaction mixture was analyzed by GC Method 1 at $1 \mathrm{~h}, 3 \mathrm{~h}$, and $18 \mathrm{~h}$. 3a, $t_{R} 5.39 \mathrm{~min}$ (was not detected).

\section{Table 1, entry 5:}

Following General Procedure I, APC (4.5 mg, $0.012 \mathrm{mmol}, 0.05$ equiv), bis(diphenylphosphino)butane (10.0 mg, $0.023 \mathrm{mmol}, 0.1$ equiv), 4-bromoacetophenone (51.1 $\mathrm{mg}, 0.26 \mathrm{mmol}$ ), 1,3,5,7-tetramethyl-1,3,5,7-tetravinylcyclotetrasiloxane (26 mg, $0.075 \mathrm{mmol}$, 0.29 equiv), and $\operatorname{TBAF}(0.5 \mathrm{~mL}, 1 \mathrm{M}$ in THF, $0.5 \mathrm{mmol}, 1.9$ equiv) were stirred at room temperature for $18 \mathrm{~h}$. An aliquot of the reaction mixture was analyzed by GC Method 1 at $1 \mathrm{~h}, 3$ h, and $18 \mathrm{~h}$ : 3a $t_{R} 5.39 \mathrm{~min}$ (was not detected).

\section{Table 1, entry 6:}

Following General Procedure I, APC (4.4 mg, $0.012 \mathrm{mmol}, 0.05$ equiv), triphenylarsine (7.65 mg, $0.025 \mathrm{mmol}, 0.1$ equiv), 4-bromoacetophenone (51.5 mg, $0.26 \mathrm{mmol}), 1,3,5,7-$ 
tetramethyl-1,3,5,7-tetravinylcyclotetrasiloxane $(26.2 \mathrm{mg}, 0.076 \mathrm{mmol}, 0.29$ equiv), and TBAF (0.5 mL, $1 \mathrm{M}$ in THF, $0.5 \mathrm{mmol}, 1.9$ equiv) were stirred at room temperature for $18 \mathrm{~h}$. An aliquot of the reaction mixture was analyzed by GC Method 1 at $1 \mathrm{~h}, 3 \mathrm{~h}$, and $18 \mathrm{~h}$. 3a $t_{R} 5.39$ $\min$ (was not detected).

\section{Table 1, entry 7:}

Following General Procedure I, APC (4.5 mg, $0.012 \mathrm{mmol}, 0.05$ equiv), 2-(di-tbutylphosphino)biphenyl (7.5 mg, $0.025 \mathrm{mmol}, 0.1$ equiv), 4-bromoacetophenone (51.5 mg, 0.26 $\mathrm{mmol}$ ), 1,3,5,7-tetramethyl-1,3,5,7-tetravinylcyclotetrasiloxane (27 mg, $0.078 \mathrm{mmol}, 0.3 \mathrm{equiv}$ ), and TBAF $(0.5 \mathrm{~mL}, 1 \mathrm{M}$ in THF, $0.5 \mathrm{mmol}, 2$ equiv) were stirred at room temperature for $18 \mathrm{~h}$. An aliquot of the reaction mixture was analyzed by GC Method $1.18 \mathrm{~h}: 3 \mathbf{a} t_{R} 5.39 \mathrm{~min}(54 \%)$.

\section{Table 1, entry 8:}

Following General Procedure I, palladium bromide (13 mg, $0.048 \mathrm{mmol}, 0.1$ equiv), 2(di-t-butylphosphino)biphenyl (17.5 mg, $0.058 \mathrm{mmol}, 0.11$ equiv), 4-bromoacetophenone (101.1 $\mathrm{mg}, 0.5 \mathrm{mmol})$, 1,3,5,7-tetramethyl-1,3,5,7-tetravinylcyclotetrasiloxane (54.6 mg, $0.16 \mathrm{mmol}$, 0.3 equiv), and TBAF ( $1 \mathrm{~mL}, 1 \mathrm{M}$ in THF, $1 \mathrm{mmol}, 2$ equiv) were stirred at room temperature for $18 \mathrm{~h}$. An aliquot of the reaction mixture was analyzed by GC Method 1. $3 \mathrm{~h}: 3 \mathbf{a} \mathrm{t}_{\mathrm{R}} 5.39 \mathrm{~min}$ (41\%), 18 h: 3a $t_{R} 5.39 \min (100 \%)$.

\section{Table 1, entry 9:}

Following General Procedure I, palladium bromide (13.3 mg, $0.05 \mathrm{mmol}, 0.1$ equiv), 2(di-cyclohexylphosphino)biphenyl (17.5 mg, $0.05 \mathrm{mmol}, 0.1$ equiv), 4-bromoacetophenone (101.1 mg, $0.5 \mathrm{mmol}$ ), 1,3,5,7-tetramethyl-1,3,5,7-tetravinylcyclotetrasiloxane (55 $\mathrm{mg}, 0.16$ mmol, 0.3 equiv), and TBAF ( $1 \mathrm{~mL}, 1 \mathrm{M}$ in THF, $1 \mathrm{mmol}, 2$ equiv) were stirred at room temperature for $3 \mathrm{~h}$. An aliquot of the reaction mixture was analyzed by GC Method 1. $1 \mathrm{~h}: 3 \mathbf{3}$ $\mathrm{t}_{\mathrm{R}} 5.39 \mathrm{~min}$ (was not detected), $3 \mathrm{h:} \mathbf{3 a} t_{R} 5.39 \mathrm{~min}$ (was not detected).

\section{Table 1, entry 10:}

Following General Procedure I, palladium bromide (13.3 mg, $0.05 \mathrm{mmol}, 0.1$ equiv), 2(di-t-butylphosphino)biphenyl (15.2 mg, $0.05 \mathrm{mmol}, 0.1$ equiv), 4-bromoacetophenone (101.1 
$\mathrm{mg}, 0.5 \mathrm{mmol})$, 1,3,5,7-tetramethyl-1,3,5,7-tetravinylcyclotetrasiloxane (54.6 mg, $0.16 \mathrm{mmol}$, 0.3 equiv), and TBAF ( $1 \mathrm{~mL}, 1 \mathrm{M}$ in THF, $1 \mathrm{mmol}, 2$ equiv) were stirred at $50{ }^{\circ} \mathrm{C}$ for $3 \mathrm{~h}$. An aliquot of the reaction mixture was analyzed by GC Method $1.3 \mathrm{~h}: 3 \mathbf{3 a} t_{R} 5.39 \mathrm{~min}(100 \%)$.

\section{General Procedure III: Vinylation of Aryl Bromides with 1,3,5,7-tetramethyl-1,3,5,7- tetravinylcyclotetrasiloxane at $50^{\circ} \mathrm{C}$}

Table 2, entry 1: Preparation of 1-(4-ethynylphenyl)ethanone (3a)

To an oven-dried, 5-mL condenser flask equipped with a magnetic stir bar and nitrogen inlet was added 2-(di-t-butylphosphino)biphenyl (15.1 mg, $0.05 \mathrm{mmol}, 0.05$ equiv). The flask was then evacuated and refilled with argon, and this evacuation/refill process was repeated two additional times. A solution of 1,3,5,7-tetramethyl-1,3,5,7-tetravinylcyclotetrasiloxane (101.2 $\mathrm{mg}, 0.3 \mathrm{mmol}, 0.3$ equiv) in THF $(0.1 \mathrm{~mL})$, followed by TBAF $(2 \mathrm{~mL}, 1 \mathrm{M}$ in THF, $2 \mathrm{mmol}, 2.0$ equiv) were then sequentially added to the flask, and the resulting mixture was allowed to stir for $10 \mathrm{~min}$ at room temperature. 4-Bromoacetophenone (199.5 $\mathrm{mg}, 1.0 \mathrm{mmol}$ ) and palladium bromide ( $13.3 \mathrm{mg}, 0.05 \mathrm{mmol}, 0.05$ equiv) were then added, and the reaction was warmed to 50 ${ }^{\circ} \mathrm{C}$ in an oil bath. GC analysis at $3 \mathrm{~h}$ indicated that no bromide remained, and the reaction was allowed to cool to room temperature. Diethyl ether $(10 \mathrm{~mL})$ was added and the mixture was stirred for $10 \mathrm{~min}$ at room temperature then was filtered through a short pad of silica $(5 \mathrm{~g})$. The silica pad was washed with diethyl ether $(25 \mathrm{~mL})$, and the combined filtrates were concentrated in vacuo to afford $160 \mathrm{mg}$ of crude material. Purification by column chromatography (hexane/ethyl acetate (40:1), $\mathrm{SiO}_{2}, 125 \mathrm{~mm}$ x $40 \mathrm{~mm}$ ) gave $125 \mathrm{mg}(85 \%)$ of 3a as a white solid.

\section{Table 2, entry 2:Preparation of 2-Vinylnaphthalene (3b)}

Following General Procedure III, 2-(di-t-butylphosphino)biphenyl (15.0 mg, $0.05 \mathrm{mmol}$, 0.05 equiv), 1,3,5,7-tetramethyl-1,3,5,7-tetravinylcyclotetrasiloxane (109 mg, $0.3 \mathrm{mmol}, 0.3$ equiv) in THF $(0.1 \mathrm{~mL})$, TBAF ( $2 \mathrm{~mL}, 1 \mathrm{M}$ in THF, $2 \mathrm{mmol}, 2.0$ equiv), 2-bromonaphthalene (207 $\mathrm{mg}, 1.0 \mathrm{mmol})$ and palladium bromide (13.3 $\mathrm{mg}, 0.05 \mathrm{mmol}, 0.05$ equiv) were combined and warmed to $50{ }^{\circ} \mathrm{C}$ in an oil bath. GC analysis at $3 \mathrm{~h}$ indicated that no bromide remained, and the reaction was allowed to cool to room temperature. Diethyl ether $(10 \mathrm{~mL})$ was added and the mixture was stirred for $10 \mathrm{~min}$ at room temperature then filtered through a short pad of silica (5 g). The silica pad was washed with diethyl ether $(25 \mathrm{~mL})$, and the combined filtrates were 
concentrated in vacuo and immediately purified by column chromatography (hexane/ethyl acetate (40:1), $\mathrm{SiO}_{2}, 125 \mathrm{~mm}$ x $\left.40 \mathrm{~mm}\right)$ gave $127 \mathrm{mg}(82 \%)$ of $\mathbf{3 b}$ as a white solid.

\section{Table 2, entry 3: Preparation of 1-Ethenyl-4-methoxybenzene (3c)}

Following General Procedure III, 2-(di-t-butylphosphino)biphenyl (15.0 mg, $0.05 \mathrm{mmol}$, 0.05 equiv), 1,3,5,7-tetramethyl-1,3,5,7-tetravinylcyclotetrasiloxane (109 mg, $0.3 \mathrm{mmol}, 0.3$ equiv) in THF ( $0.1 \mathrm{~mL})$, TBAF ( $2 \mathrm{~mL}, 1 \mathrm{M}$ in THF, $2 \mathrm{mmol}, 2.0$ equiv), 4-bromoanisole (207 $\mathrm{mg}, 1.0 \mathrm{mmol})$ and palladium bromide (13.3 $\mathrm{mg}, 0.05 \mathrm{mmol}, 0.05$ equiv) were combined, and the reaction was warmed to $50{ }^{\circ} \mathrm{C}$ in an oil bath. $\mathrm{GC}$ analysis at $3 \mathrm{~h}$ indicated that no bromide remained, and the reaction was allowed to cool to room temperature. To the cooled mixture was added diethyl ether $(10 \mathrm{~mL})$ and allowed to stir for $10 \mathrm{~min}$ at room temperature, after which the mixture was filtered through a short pad of silica, washed with diethyl ether $(25 \mathrm{~mL})$, and concentrated in vacuo to afford $147 \mathrm{mg}$ of crude material. Purification by column chromatography (hexane/ethyl acetate (40:1), $\mathrm{SiO}_{2}, 150 \mathrm{~mm}$ x $40 \mathrm{~mm}$ ) gave $43 \mathrm{mg}(32 \%)$ of 3c as a clear oil.

\section{Table 3, entry 1: (See Table 2, entry 3)}

\section{Table 3, entry 2:}

Following General Procedure I, 2-(di-t-butylphosphino)biphenyl (7.5 mg, $0.025 \mathrm{mmol}$, 0.05 equiv), 1,3,5,7-tetramethyl-1,3,5,7-tetravinylcyclotetrasiloxane (51.1 mg, $0.15 \mathrm{mmol}, 0.3$ equiv) in THF (0.1 mL), TBAF ( $1 \mathrm{~mL}, 1 \mathrm{M}$ in THF, $1 \mathrm{mmol}, 2.0$ equiv), 4-bromoanisole (93.5 $\mathrm{mg}, 0.5 \mathrm{mmol})$, hexamethylbenzene $(4.9 \mathrm{mg}, 0.03 \mathrm{mmol})$ and palladium bromide $(6.5 \mathrm{mg}, 0.025$ mmol, 0.05 equiv) were combined, and the reaction was warmed to $70{ }^{\circ} \mathrm{C}$ in an oil bath. A $3 \mathrm{~h}$ aliquot was analyzed by ${ }^{1} \mathrm{H}-\mathrm{NMR}$ spectroscopy. The yield was determined by the integration of 8 versus the internal standard which was normalized to 18 . The ratio of styrene/stilbene was determined by relative integration. $\quad 3 c(3.81 \mathrm{ppm}, 3 \mathrm{H}, 32.16,67 \%)$, stilbene $(3.83 \mathrm{ppm}, 6 \mathrm{H}$, $11.83,12 \%) 3 \mathbf{c} /$ stilbene $(5.4: 1)$. 


\section{Table 3, entry 3:}

Following General Procedure II, TBAF (630 mg, 2 mmol, 2 equiv) dimethoxyethane (2 $\mathrm{mL}), 1,3,5,7$-tetramethyl-1,3,5,7-tetravinylcyclotetrasiloxane (111 mg, $0.32 \mathrm{mmol}, 0.32 \mathrm{equiv})$ in DME (0.1 mL), 2-(di-t-butylphosphino)biphenyl (15.1 mg, $0.05 \mathrm{mmol}, 0.05$ equiv), hexamethylbenzene $(6.5 \mathrm{mg}, 0.04 \mathrm{mmol})$, 4-bromoanisole $(187 \mathrm{mg}, 1.0 \mathrm{mmol})$ and palladium bromide (13.3 mg, $0.05 \mathrm{mmol}, 0.05$ equiv) were combined and the reaction was heated to reflux in an oil bath. A $3 \mathrm{~h}$ aliquot was analyzed by ${ }^{1} \mathrm{H}-\mathrm{NMR}$ spectroscopy. The yield was determined by the integration of $\mathbf{3 c}$ versus the internal standard which was normalized to 18 . The ratio of styrene/stilbene was determined by relative integration. $\quad 3 c(3.81 \mathrm{ppm}, 3 \mathrm{H}, 47.66,64 \%)$, stilbene (3.83 ppm, $6 \mathrm{H}, 19.18,13 \%)$ 3c/stilbene (5.0:1).

\section{Table 3, entry 4:}

Following General Procedure II, TBAF (630 mg, $2 \mathrm{mmol}, 2$ equiv), dioxane (2 mL) a solution of 1,3,5,7-tetramethyl-1,3,5,7-tetravinylcyclotetrasiloxane $(111 \mathrm{mg}, 0.32 \mathrm{mmol}, 0.32$ equiv) in dioxane $(0.1 \mathrm{~mL}), 2$-(Di-t-butylphosphino)biphenyl (15.1 mg, $0.05 \mathrm{mmol}, 0.05$ equiv), hexamethylbenzene $(8.7 \mathrm{mg}, 0.053 \mathrm{mmol})$, 4-bromoanisole $(187 \mathrm{mg}, 1.0 \mathrm{mmol})$ and palladium bromide (13.3 mg, $0.05 \mathrm{mmol}, 0.05$ equiv) were combined, and the reaction was heated to reflux in an oil bath. A $3 \mathrm{~h}$ aliquot was analyzed by ${ }^{1} \mathrm{H}-\mathrm{NMR}$ spectroscopy. The yield was determined by the integration of $\mathbf{3 c}$ versus the internal standard which was normalized to 18 . The ratio of styrene/stilbene was determined by relative integration. 3c (3.81 ppm, $3 \mathrm{H}, 39.62,70 \%)$, stilbene (3.83 ppm, $6 \mathrm{H}, 13.35,12 \%)$, 3c/stilbene (5.9:1).

\section{Table 3, entry 5:}

Following General Procedure I, 2-(di-t-butylphosphino)biphenyl $(7.5 \mathrm{mg}, 0.025 \mathrm{mmol}$, 0.05 equiv), 1,3,5,7-tetramethyl-1,3,5,7-tetravinylcyclotetrasiloxane (110 mg, $0.32 \mathrm{mmol}, 0.6$ equiv) in THF ( $0.1 \mathrm{~mL})$, TBAF ( $2 \mathrm{~mL}, 1 \mathrm{M}$ in THF, $2 \mathrm{mmol}, 4.0$ equiv), 4-bromoanisole (93.5 $\mathrm{mg}, 0.5 \mathrm{mmol})$, hexamethylbenzene $(8.6 \mathrm{mg}, 0.053 \mathrm{mmol})$ and palladium bromide $(6.5 \mathrm{mg}$, $0.025 \mathrm{mmol}, 0.05$ equiv) were combined, and the reaction was warmed to $70{ }^{\circ} \mathrm{C}$ in an oil bath. A $1 \mathrm{~h}$ aliquot was analyzed by ${ }^{1} \mathrm{H}-\mathrm{NMR}$ spectroscopy. The yield was determined by the integration of $3 \mathbf{c}$ versus the internal standard which was normalized to 18 . The ratio of styrene/stilbene was 
determined by relative integration. $\quad 3 c(3.81 \mathrm{ppm}, 3 \mathrm{H}, 20.71,74 \%)$, stilbene $(3.83 \mathrm{ppm}, 6 \mathrm{H}$, 1.53, $3 \%) 3 c /$ stilbene $(27: 1)$.

\section{Table 3, entry 6:}

Following General Procedure I, 2-(di-t-butylphosphino)biphenyl (7.5 mg, $0.025 \mathrm{mmol}$, 0.05 equiv), 1,3,5,7-tetramethyl-1,3,5,7-tetravinylcyclotetrasiloxane (153 mg, $0.44 \mathrm{mmol}, 0.88$ equiv) in THF ( $0.1 \mathrm{~mL})$, TBAF ( $3 \mathrm{~mL}, 1 \mathrm{M}$ in THF, $3 \mathrm{mmol}, 6.0$ equiv), 4-bromoanisole (93.5 $\mathrm{mg}, 0.5 \mathrm{mmol})$, hexamethylbenzene $(8.8 \mathrm{mg}, 0.054 \mathrm{mmol})$ and palladium bromide $(6.5 \mathrm{mg}$, $0.025 \mathrm{mmol}, 0.05$ equiv) were combined, and the reaction was warmed to $70{ }^{\circ} \mathrm{C}$ in an oil bath. A $1 \mathrm{~h}$ aliquot was analyzed by ${ }^{1} \mathrm{H}-\mathrm{NMR}$ spectroscopy. The yield was determined by the integration of $3 \mathbf{c}$ versus the internal standard which was normalized to 18 . The ratio of styrene/stilbene was determined by relative integration. $\quad 3 c(3.81 \mathrm{ppm}, 3 \mathrm{H}, 25.77,93 \%)$, stilbene $(3.83 \mathrm{ppm}, 6 \mathrm{H}$, $0.06,0.1 \%) 3 c /$ stilbene $(>99: 1)$.

\section{Table 3, entry 7:}

Following General Procedure I, 2-(di-t-butylphosphino)biphenyl (7.5 mg, $0.025 \mathrm{mmol}$, 0.05 equiv), 1,3,5,7-tetramethyl-1,3,5,7-tetravinylcyclotetrasiloxane (154 mg, $0.45 \mathrm{mmol}, 0.9$ equiv) in THF $(0.1 \mathrm{~mL})$, TBAF $(1.8 \mathrm{~mL}, 1 \mathrm{M}$ in THF, $1.8 \mathrm{mmol}, 3.6$ equiv), 4-bromoanisole (93.5 $\mathrm{mg}, 0.5 \mathrm{mmol})$, hexamethylbenzene $(4.7 \mathrm{mg}, 0.029 \mathrm{mmol})$ and palladium bromide $(6.5 \mathrm{mg}$, $0.025 \mathrm{mmol}, 0.05$ equiv) were combined, and the reaction was warmed to $70{ }^{\circ} \mathrm{C}$ in an oil bath. A $2 \mathrm{~h}$ aliquot was analyzed by ${ }^{1} \mathrm{H}-\mathrm{NMR}$ spectroscopy. The yield was determined by the integration of $3 \mathbf{c}$ versus the internal standard which was normalized to 18 . The ratio of styrene/stilbene was determined by relative integration. $\quad 3 c(3.81 \mathrm{ppm}, 3 \mathrm{H}, 48.73,94 \%)$, stilbene $(3.83 \mathrm{ppm}, 6 \mathrm{H}$, 2.56, $2 \%)$ 3c/stilbene (38:1).

\section{Table 3, entry 8:}

Following General Procedure II, 2-(di-t-butylphosphino)biphenyl (15 mg, $0.05 \mathrm{mmol}$, 0.05 equiv), 1,3,5,7-tetramethyl-1,3,5,7-tetravinylcyclotetrasiloxane (309 mg, $0.9 \mathrm{mmol}, 0.9$ equiv) in THF ( $0.1 \mathrm{~mL})$, TBAF ( $4 \mathrm{~mL}, 1 \mathrm{M}$ in THF, $4 \mathrm{mmol}, 4.0$ equiv), 4-bromoanisole (174 $\mathrm{mg}, 1.0 \mathrm{mmol})$, hexamethylbenzene $(13.2 \mathrm{mg}, 0.081 \mathrm{mmol})$ and palladium bromide $(13.3 \mathrm{mg}$, $0.05 \mathrm{mmol}, 0.05$ equiv) were combined, and the reaction was warmed to $70{ }^{\circ} \mathrm{C}$ in an oil bath. A 
$2 \mathrm{~h}$ aliquot was analyzed by ${ }^{1} \mathrm{H}-\mathrm{NMR}$ spectroscopy. The yield was determined by the integration of $3 \mathbf{c}$ versus the internal standard which was normalized to 18 . The ratio of styrene/stilbene was determined by relative integration. $3 c(3.81 \mathrm{ppm}, 3 \mathrm{H}, 48.73,94 \%)$, stilbene $(3.83 \mathrm{ppm}, 6 \mathrm{H}$, was not observed, $<1 \%)$ 3c/stilbene $(>99: 1)$.

\section{Scheme 2, entry 1:}

To an oven-dried, 5-mL condenser flask equipped with a magnetic stir bar and nitrogen inlet was added 2-(di-t-butylphosphino)biphenyl ( $7.5 \mathrm{mg}, 0.025 \mathrm{mmol}, 0.05$ equiv), palladium bromide (6.6 mg, $0.025 \mathrm{mmol}, 0.05$ equiv). The flask was then evacuated and refilled with argon, and this evacuation/refill process was repeated two additional times. A solution of 1,3,5,7-tetramethyl-1,3,5,7-tetravinylcyclotetrasiloxane (154 mg, $0.45 \mathrm{mmol}, 0.9$ equiv) in THF $(0.1 \mathrm{~mL})$, followed by TBAF ( $2 \mathrm{~mL}, 1 \mathrm{M}$ in THF, $2 \mathrm{mmol}, 4.0$ equiv) were then sequentially added to the flask, and the resulting mixture was allowed to stir for $10 \mathrm{~min}$ at room temperature. 1-Bromonaphthalene $(103.5 \mathrm{mg}, 0.5 \mathrm{mmol})$ was then added via syringe, and the reaction was warmed to $70{ }^{\circ} \mathrm{C}$ in an oil bath. Two aliquots, $2.5 \mathrm{~h}$ and $5 \mathrm{~h}$, were analyzed by ${ }^{1} \mathrm{H}-\mathrm{NMR}$ spectroscopy. The conversion and styrene/stilbene ratio were determined by relative integration. 5 h: 2b (8.21 ppm, 1 H, was not detected, 0 \%), 3b (8.15 ppm, 1 H, 6.29, 86 \%), 7 (8.27 ppm, 2 H, $1.99,14 \%) 3 \mathbf{b} / 7(6.3: 1)$.

\section{General Procedure IV: Vinylation of Aryl Bromides using 2.0 Equivalents of 2-(di-t-} butylphosphino)biphenyl.

\section{Scheme 2, entry 2:}

To an oven-dried, 10-mL, 2-necked, round-bottomed flask equipped with a magnetic stir bar, septum and nitrogen inlet was added 2-(di-t-butylphosphino)biphenyl (15.1 mg, $0.05 \mathrm{mmol}$, 0.10 equiv), palladium bromide $(6.6 \mathrm{mg}, 0.025 \mathrm{mmol}, 0.05$ equiv). The flask was then evacuated and refilled with argon, and this evacuation/refill process was repeated two additional times. A solution of 1,3,5,7-tetramethyl-1,3,5,7-tetravinylcyclotetrasiloxane (51 mg, $0.15 \mathrm{mmol}, 0.3$ equiv) in THF (0.1 mL), followed by TBAF ( $1 \mathrm{~mL}, 1 \mathrm{M}$ in THF, $1 \mathrm{mmol}, 2.0$ equiv) were then sequentially added to the flask, and the resulting mixture was allowed to stir for 10 min at room temperature. 1-Bromonaphthalene $(103.4 \mathrm{mg}, 0.5 \mathrm{mmol})$ was then added via syringe, and the reaction was stirred at room temperature for $1 \mathrm{~h}$. A $1 \mathrm{~h}$ aliquot was analyzed by ${ }^{1} \mathrm{H}-\mathrm{NMR}$ 
spectroscopy, showing no product. The reaction was warmed to $50{ }^{\circ} \mathrm{C}$ in an oil bath. A $1.5 \mathrm{~h}$ (0.5 h after warming) aliquot was analyzed by ${ }^{1} \mathrm{H}-\mathrm{NMR}$ spectroscopy. The conversion and styrene/stilbene ratio were determined by relative integration. $\mathbf{2 b}(8.21 \mathrm{ppm}, 1 \mathrm{H}$, was not detected, 0 \%), $3 \mathbf{b}$ (8.15 ppm, 1 H, 1.00, $87 \%), 7$ (8.27 ppm, 2 H, 0.31, 13 \%) 3b/7 (6.4:1).

\section{Table 4, entry 1:}

To an oven-dried, 10-mL, 2-necked, round-bottomed flask equipped with a magnetic stir bar, septum and nitrogen inlet was added 2-(di-t-butylphosphino)biphenyl (15.1 mg, $0.05 \mathrm{mmol}$, 0.10 equiv), palladium bromide $(6.6 \mathrm{mg}, 0.025 \mathrm{mmol}, 0.05$ equiv). The flask was then evacuated and refilled with argon, and this evacuation/refill process was repeated two additional times. A solution of 1,3,5,7-tetramethyl-1,3,5,7-tetravinylcyclotetrasiloxane $(51 \mathrm{mg}, 0.15 \mathrm{mmol}, 0.3$ equiv) in THF (0.1 mL), followed by TBAF ( $1 \mathrm{~mL}, 1 \mathrm{M}$ in THF, $1 \mathrm{mmol}, 2.0$ equiv) were then sequentially added to the flask, and the resulting mixture was allowed to stir for 10 min at room temperature. 1-Bromonaphthalene $(103.4 \mathrm{mg}, 0.5 \mathrm{mmol})$ was then added via syringe, and the reaction was stirred at room temperature for $6 \mathrm{~h}$. Two aliquots, $3 \mathrm{~h}$ and $6 \mathrm{~h}$, were analyzed by ${ }^{1} \mathrm{H}-$ NMR spectroscopy. The conversion and styrene/stilbene ratio were determined by relative integration. 6 h: $2 \mathbf{b}(8.21$ ppm, $1 \mathrm{H}$, was not detected, $0 \%), 3 \mathbf{b}(8.15$ ppm, $1 \mathrm{H}, 1.00,91 \%), 7$ (8.27 ppm, $2 \mathrm{H}, 0.20,9 \%)$ 3b/7 (10:1).

\section{Table 4, Entry 2, (See Scheme 2, Entry 2 above)}

\section{Table 4, Entry 3}

Following General Procedure IV, 2-(di-t-butylphosphino)biphenyl (7.5 mg, 0.025 mmol, 0.05 equiv), palladium bis(dibenzylideneacetone) (14.1 mg, $0.025 \mathrm{mmol}, 0.05$ equiv), a solution of 1,3,5,7-tetramethyl-1,3,5,7-tetravinylcyclotetrasiloxane (51 mg, $0.15 \mathrm{mmol}, 0.3$ equiv) in THF $(0.1 \mathrm{~mL})$, TBAF $(1 \mathrm{~mL}, 1 \mathrm{M}$ in THF, $1 \mathrm{mmol}, 2.0$ equiv) and 1-bromonaphthalene (103.4 mg, $0.5 \mathrm{mmol}$ ) were combined, and the mixture was warmed to $50{ }^{\circ} \mathrm{C}$ and stirred for $6 \mathrm{~h}$. Three aliquots, $30 \mathrm{~min}, 2 \mathrm{~h}$ and $6 \mathrm{~h}$, were analyzed by ${ }^{1} \mathrm{H}-\mathrm{NMR}$ spectroscopy. The conversion and styrene/stilbene ratio were determined by relative integration. $6 \mathrm{~h}: \mathbf{2 b}(8.21 \mathrm{ppm}, 1 \mathrm{H}, 0.10,9$ \%), 3b (8.15 ppm, 1 H, 0.99, 87 \%), 7 (8.27 ppm, 2 H, 0.10, 4 \%) 3b/7 (19:1). 


\section{Table 4, Entry 4}

Following General Procedure IV, 2-(di-t-butylphosphino)biphenyl (15 mg, $0.05 \mathrm{mmol}$, 0.10 equiv), palladium bromide ( $6.6 \mathrm{mg}, 0.025 \mathrm{mmol}, 0.05$ equiv), a solution of 1,3,5,7tetramethyl-1,3,5,7-tetravinylcyclotetrasiloxane $(68.8 \mathrm{mg}, 0.2 \mathrm{mmol}, 0.4$ equiv) in THF $(0.1$ $\mathrm{mL})$, TBAF (1 mL, $1 \mathrm{M}$ in THF, $1 \mathrm{mmol}, 2.0$ equiv) and 1-bromonaphthalene (103.4 mg, 0.5 mmol) were combined, and the mixture was warmed to $50{ }^{\circ} \mathrm{C}$ and stirred for $1 \mathrm{~h}$. A $1 \mathrm{~h}$ aliquot was analyzed by ${ }^{1} \mathrm{H}-\mathrm{NMR}$ spectroscopy. The conversion and styrene/stilbene ratio were determined by relative integration. $\mathbf{2 b}(8.21$ ppm, $1 \mathrm{H}, 1.00,6 \%), \mathbf{3 b}(8.15$ ppm, $1 \mathrm{H}, 16.13,92$ \%), 7 (8.27 ppm, 2 H, 1.00, 3 \%) 3b/7 (6.4:1).

\section{Table 4, Entry 5}

Following General Procedure IV, 2-(di-t-butylphosphino)biphenyl (15.1 mg, $0.05 \mathrm{mmol}$, 0.10 equiv), palladium bromide $(6.6 \mathrm{mg}, 0.025 \mathrm{mmol}, 0.05$ equiv), a solution of 1,3,5,7tetramethyl-1,3,5,7-tetravinylcyclotetrasiloxane ( $86 \mathrm{mg}, 0.25 \mathrm{mmol}, 0.5$ equiv) in THF $(0.1 \mathrm{~mL})$, TBAF (1 mL, $1 \mathrm{M}$ in THF, $1 \mathrm{mmol}, 2.0$ equiv) and 1-bromonaphthalene (103.4 mg, $0.5 \mathrm{mmol})$ were combined, and the mixture was warmed to $50{ }^{\circ} \mathrm{C}$ and stirred for $2.5 \mathrm{~h}$. Two aliquots, $2 \mathrm{~h}$ and $2.5 \mathrm{~h}$, were analyzed by ${ }^{1} \mathrm{H}-\mathrm{NMR}$ spectroscopy. The conversion and styrene/stilbene ratio were determined by relative integration. $2.5 \mathrm{~h}: \mathbf{2 b}(8.21 \mathrm{ppm}, 1 \mathrm{H}$, was not detected, $0 \%), 3 \mathbf{b}$ (8.15 ppm, 1 H, 32.01, 97 \%), 7 (8.27 ppm, 2 H, 2.00, 3 \%) 3b/7 (32:1). 


\section{General Procedure V: Preparative Vinylation of Aryl Bromides}

\section{Preparation of 1-(4-Ethenylphenyl)ethanone (3a) ${ }^{4}$}

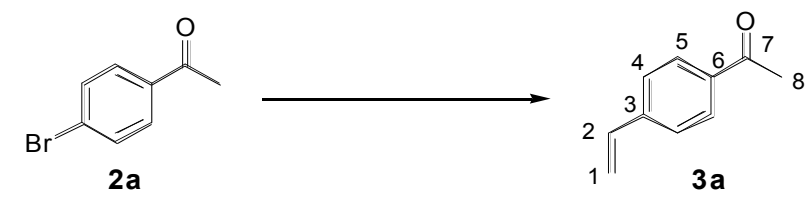

To an oven-dried, 10-mL, 2-necked, round-bottomed flask equipped with a magnetic stir bar, septum and nitrogen inlet was added 2-(di-t-butylphosphino)biphenyl (59.6 mg, $0.20 \mathrm{mmol}$, 0.10 equiv), palladium bromide $(26.6 \mathrm{mg}, 0.1 \mathrm{mmol}, 0.05$ equiv). The flask was then evacuated and refilled with argon, and this evacuation/refill process was repeated two additional times. A solution of 1,3,5,7-tetramethyl-1,3,5,7-tetravinylcyclotetrasiloxane (344 mg, $1.0 \mathrm{mmol}, 0.5$ equiv) in THF ( $0.1 \mathrm{~mL})$, followed by TBAF ( $4 \mathrm{~mL}, 1 \mathrm{M}$ in THF, $4 \mathrm{mmol}, 2.0$ equiv) were then sequentially added to the flask, and the resulting mixture was allowed to stir for $10 \mathrm{~min}$ at room temperature. 4-Bromoacetophenone $(398.0 \mathrm{mg}, 2.0 \mathrm{mmol})$ was then added via syringe, and the reaction was warmed to $50{ }^{\circ} \mathrm{C}$ in an oil bath. $\mathrm{GC}$ analysis at $4 \mathrm{~h}$ indicated that no bromide remained, and the reaction was allowed to cool to room temperature. Diethyl ether $(10 \mathrm{~mL})$ was added and the mixture was stirred for $10 \mathrm{~min}$ at room temperature then filtered through a short pad of silica $(5 \mathrm{~g})$. The silica pad was washed with diethyl ether $(50 \mathrm{~mL})$, and the combined filtrates were concentrated in vacuo to afford $645 \mathrm{mg}$ of crude material. Purification by column chromatography (hexane/ethyl acetate (50:1), $\mathrm{SiO}_{2}, 160 \mathrm{~mm}$ x $40 \mathrm{~mm}$ ) gave $265 \mathrm{mg}(91 \%)$ of 3a as a white solid.

Data for 3a:

mp: $\quad 33-34{ }^{\circ} \mathrm{C}$

${ }^{1}$ H NMR: $\quad\left(500 \mathrm{MHz}, \mathrm{CDCl}_{3}\right)$

$7.92(\mathrm{~d}, J=8.6,2 \mathrm{H}, \mathrm{HC}(3)), 7.48(\mathrm{~d}, J=8.4,2 \mathrm{H}, \mathrm{HC}(4)), 6.76(\mathrm{dd}, J=17.6$ and $10.9,1 \mathrm{H}, \mathrm{HC}(2)), 5.88\left(\mathrm{dd}, J=17.6\right.$ and $\left.0.6,1 \mathrm{H}, \mathrm{H}_{\text {trans }} \mathrm{C}(1)\right), 5.39(\mathrm{dd}, J=10.9$ and $\left.0.6,1 \mathrm{H}, \mathrm{H}_{\mathrm{cis}} \mathrm{C}(1)\right), 2.60(\mathrm{~s}, 3 \mathrm{H}, \mathrm{HC}(8))$.

${ }^{13} \mathrm{C} \mathrm{NMR:} \quad\left(125 \mathrm{MHz},\left(\mathrm{CDCl}_{3}\right)\right.$

$197.9(\mathrm{C}(7)), 142.3(\mathrm{C}(3)), 136.5(\mathrm{C}(6)), 136.2$ (C(2)), $128.9(\mathrm{C}(5)), 126.5(\mathrm{C}(4))$, $117.0(\mathrm{C}(1)), 26.8(\mathrm{C}(8))$.

IR: $\quad 3054(\mathrm{~m}), 2987(\mathrm{w}), 2306(\mathrm{w}), 1681(\mathrm{~m}), 1605(\mathrm{w}), 1422(\mathrm{w}), 1359(\mathrm{w}), 1265(\mathrm{~s})$, $1181(w), 957(w), 922(w), 896(w), 847(w), 739(s), 705(s)$. 
MS: $\quad(\mathrm{EI}, 70 \mathrm{eV})$

$146\left(\mathrm{M}^{+}, 41\right), 132(11), 131$ (100), 103 (48), 77 (28).

$\underline{R}_{f:} \quad 0.07$ (hexane/ethyl acetate, $50: 1$ )

\section{Preparation of 1-Ethenylnaphthalene (3b) ${ }^{5}$}

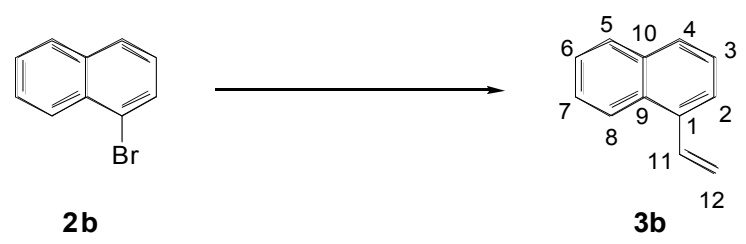

Following General Procedure V, 2-(di-t-butylphosphino)biphenyl (59.4 mg, $0.20 \mathrm{mmol}$, 0.10 equiv), palladium bromide (26.6 mg, $0.1 \mathrm{mmol}, 0.05$ equiv), a solution of 1,3,5,7tetramethyl-1,3,5,7-tetravinylcyclotetrasiloxane $(344 \mathrm{mg}, 1.0 \mathrm{mmol}, 0.5$ equiv) in THF $(0.1 \mathrm{~mL})$, TBAF (4 mL, 1 M in THF, $4 \mathrm{mmol}, 2.0$ equiv) and 1-bromonaphthalene (414 mg, $2.0 \mathrm{mmol}$ ) were combined, and the reaction was warmed to $50{ }^{\circ} \mathrm{C}$ in an oil bath. $\mathrm{GC}$ analysis at $3 \mathrm{~h}$ indicated that no bromide remained, and the reaction was allowed to cool to room temperature. Pentane $(10 \mathrm{~mL})$ was added and the mixture was stirred for $10 \mathrm{~min}$ at room temperature, then filtered twice through a short pad of silica $(5 \mathrm{~g})$. The silica pad was washed with pentane (50 $\mathrm{mL}$ ) and the combined filtrates were concentrated in vacuo to afford $580 \mathrm{mg}$ of crude material. Purification by column chromatography (RP C18, methanol/water (9:1), $24 \mathrm{~mm} \times 115 \mathrm{~mm}$ ) and bulb-to bulb distillation afforded $217 \mathrm{mg}(71 \%)$ of $\mathbf{3 b}$ as a clear oil.

\section{Data for $\mathbf{3 b}$}

bp: $\quad 65^{\circ} \mathrm{C}(0.1 \mathrm{~mm} \mathrm{Hg}, \mathrm{ABT})$

${ }^{1}$ H NMR: $\quad\left(500 \mathrm{MHz}, \mathrm{CDCl}_{3}\right)$

$8.15(\mathrm{~d}, J=7.9,1 \mathrm{H}, \mathrm{HC}(8)), 7.87$ (d, $1 \mathrm{H}, \mathrm{HC}(2)), 7.82$ (d, $J=8.4,1 \mathrm{H}, \mathrm{HC}(7))$, $7.65(\mathrm{dd}, J=8.1$ and 1.3, $1 \mathrm{H}, \mathrm{HC}(4)), 7.56-7.44$ (m, $4 \mathrm{H}, \mathrm{HC}(11), \mathrm{HC}(6), \mathrm{HC}(3)$, $\mathrm{HC}(5)), 5.83\left(\mathrm{dd}, J=17.5\right.$ and $\left.1.7,1 \mathrm{H}, \mathrm{H}_{\text {trans }} \mathrm{C}(12)\right), 5.51(\mathrm{dd}, J=10.9$ and $1.7,1$ $\left.\mathrm{H}, \mathrm{H}_{\mathrm{cis}} \mathrm{C}(12)\right)$.

${ }^{13} \mathrm{C}$ NMR: $\quad\left(125 \mathrm{MHz},\left(\mathrm{CDCl}_{3}\right)\right.$

135.9 (C(1)), 134.6 (C(11)), 133.8 (C(10)), 131.4 (C(9)), 128.8 (C(5), 128.4 (C(4)), 126.3 (C(7)), 126.0 (C(6)), 125.9 (3), 124.0 (C(8)), 123.9 (C(2)), 117.4 $(\mathrm{C}(12))$. 


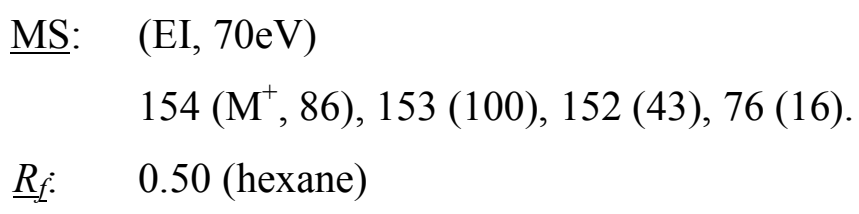

\section{Preparation of 1-Ethenyl-4-methoxybenzene (3c) ${ }^{4}$}

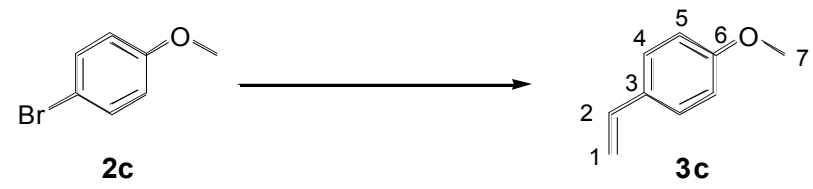

Following General Procedure V, 2-(di-t-butylphosphino)biphenyl (59.6 mg, $0.20 \mathrm{mmol}$, 0.10 equiv), palladium bromide (26.6 mg, $0.1 \mathrm{mmol}, 0.05$ equiv), a solution of 1,3,5,7tetramethyl-1,3,5,7-tetravinylcyclotetrasiloxane (344 mg, $1.0 \mathrm{mmol}, 0.5$ equiv) in THF (0.1 mL), TBAF (4 mL, $1 \mathrm{M}$ in THF, $4 \mathrm{mmol}, 2.0$ equiv), 4-bromoanisole (374 mg, $2.0 \mathrm{mmol}$ ) were combined, and the reaction was warmed to $50{ }^{\circ} \mathrm{C}$ in an oil bath. $\mathrm{GC}$ analysis at $10 \mathrm{~h}$ indicated that no bromide remained, and the reaction was allowed to cool to room temperature. Diethyl ether $(10 \mathrm{~mL})$ was added and the mixture was stirred for $10 \mathrm{~min}$ at room temperature then filtered through a short pad of silica $(5 \mathrm{~g})$. The silica pad was washed with diethyl ether $(50$ $\mathrm{mL}$ ), and the combined filtrates were concentrated in vacuo to afford $370 \mathrm{mg}$ of crude material. Purification by column chromatography (hexane/ethyl acetate (20:1), $\mathrm{SiO}_{2}, 120 \mathrm{~mm}$ x $30 \mathrm{~mm}$ ) and bulb-to-bulb distillation afforded $230 \mathrm{mg}(86 \%)$ of $\mathbf{3 c}$ as a clear oil.

\section{Data for 3c}

bp: $\quad 105{ }^{\circ} \mathrm{C}(20 \mathrm{mmHg}, \mathrm{ABT})$

${ }^{1}$ H NMR: $\quad\left(500 \mathrm{MHz}, \mathrm{CDCl}_{3}\right)$

7.35 (d, $J=9.0,2$ H, HC(4)), 6.86 (d, $J=8.9,2$ H, HC(5)), 6.66 (dd, $J=17.6$ and $10.9,1 \mathrm{H}, \mathrm{HC}(2)), 5.62\left(\mathrm{dd}, J=17.6\right.$ and $\left.0.6,1 \mathrm{H}, \mathrm{H}_{\text {trans }} \mathrm{C}(1)\right), 5.12(\mathrm{dd}, J=10.9$ and $\left.0.6,1 \mathrm{H}, \mathrm{H}_{\mathrm{cis}} \mathrm{C}(1)\right), 3.81(\mathrm{~s}, 3 \mathrm{H}, \mathrm{HC}(7))$.

${ }^{13} \mathrm{C}$ NMR: $\quad\left(125 \mathrm{MHz},\left(\mathrm{CDCl}_{3}\right)\right.$ $159.6(\mathrm{C}(6)), 136.4(\mathrm{C}(2)), 130.7(\mathrm{C}(3)), 127.6(\mathrm{C}(4)), 114.1(\mathrm{C}(5)), 111.8(\mathrm{C}(1))$, $55.5(\mathrm{C}(7))$.

IR: $\quad 3086(w), 3004(\mathrm{~m}), 2956(\mathrm{~m}), 2908(\mathrm{w}), 2836(\mathrm{~m}), 2551(\mathrm{w}) 2360(\mathrm{w}), 2062(\mathrm{w})$, 1885 (w), 1812 (w), 1628 (s), 1607 (s), 1575 (m), 1511 (s), 1462 (m), 1442 (m), 
1425 (w), 1408 (w), 1320 (w), 1301 (s), 1249 (s), 1174 (s), 1114 (m), 1040 (s), 1024 (m), 990 (m), 901 (m), 835 (s), 815 (m), $741(\mathrm{w}), 709(\mathrm{w})$.

MS: $\quad(\mathrm{EI}, 70 \mathrm{eV})$

$135\left(\mathrm{M}^{+}+1,12\right), 134(100), 119(40), 91(65)$.

$\underline{R}_{f}: \quad 0.2$ (hexane/ethyl acetate, $\left.100: 1\right)$

Preparation of 4-Ethenylbenzoic acid, Ethyl Ester (3e) ${ }^{6}$

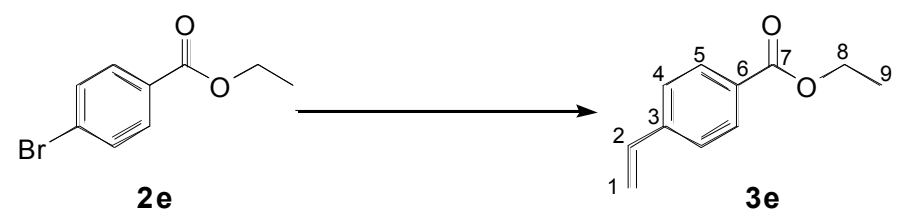

Following General Procedure V, 2-(di-t-butylphosphino)biphenyl (59.6 mg, $0.20 \mathrm{mmol}$, 0.10 equiv), palladium bromide (26.6 mg, $0.1 \mathrm{mmol}, 0.05$ equiv), a solution of 1,3,5,7tetramethyl-1,3,5,7-tetravinylcyclotetrasiloxane (344 mg, $1.0 \mathrm{mmol}, 0.5$ equiv) in THF (0.1 mL), TBAF (4 mL, $1 \mathrm{M}$ in THF, $4 \mathrm{mmol}, 2.0$ equiv), ethyl 4-bromobenzoate (460 mg, $2.0 \mathrm{mmol}$ ) were combined, and the reaction was warmed to $50{ }^{\circ} \mathrm{C}$ in an oil bath. GC analysis at $5 \mathrm{~h}$ indicated that no bromide remained, and the reaction was allowed to cool to room temperature. Diethyl ether $(10 \mathrm{~mL})$ was added and the mixture was stirred for $10 \mathrm{~min}$ at room temperature then filtered through a short pad of silica $(5 \mathrm{~g})$. The silica pad was washed with diethyl ether $(50 \mathrm{~mL})$, and the combined filtrates were concentrated in vacuo to afford $615 \mathrm{mg}$ of crude material. Purification by column chromatography (hexane/ethyl acetate (20:1), $\mathrm{SiO}_{2}, 120 \mathrm{~mm}$ x $30 \mathrm{~mm}$ ) and bulb-to-bulb distillation afforded $290 \mathrm{mg}(83 \%)$ of $3 \mathbf{e}$ as a clear oil.

\section{$\underline{\text { Data for 3e }}$}

bp: $\quad 135-140^{\circ} \mathrm{C}(0.2 \mathrm{mmHg}, \mathrm{ABT})$

${ }^{1}$ H NMR: $\quad\left(500 \mathrm{MHz}, \mathrm{CDCl}_{3}\right)$

$8.00(\mathrm{~d}, J=8.3,2 \mathrm{H}, \mathrm{HC}(4)), 7.46(\mathrm{~d}, J=8.3,2 \mathrm{H}, \mathrm{HC}(5)), 6.75(\mathrm{dd}, J=17.6$ and $10.9,1 \mathrm{H}, \mathrm{HC}(2)), 5.86\left(\mathrm{~d}, J=17.6,1 \mathrm{H}, \mathrm{H}_{\text {trans }} \mathrm{C}(1)\right), 5.38(\mathrm{~d}, J=10.9,1 \mathrm{H}$, $\left.\mathrm{H}_{\mathrm{cis}} \mathrm{C}(1)\right), 4.38$ (q, $\left.J=7.1,2 \mathrm{H}, \mathrm{HC}(8)\right), 1.40$ (t, $\left.J=7.1,3 \mathrm{H}, \mathrm{HC}(9)\right)$.

${ }^{13} \mathrm{C}$ NMR: $\quad\left(125 \mathrm{MHz},\left(\mathrm{CDCl}_{3}\right)\right.$

$166.6(\mathrm{C}(7)), 142.0(\mathrm{C}(3)), 136.3(\mathrm{C}(2)), 130.1(\mathrm{C}(5)), 129.9(\mathrm{C}(6)), 126.3(\mathrm{C}(4))$, $116.6(\mathrm{C}(1)), 61.1(\mathrm{C}(8)), 14.5(\mathrm{C}(9))$. 
IR: $\quad 3067(w), 2982(\mathrm{~m}), 2936(\mathrm{w}), 2906(\mathrm{w}), 2873(\mathrm{w}), 2332(\mathrm{w}) 1945(\mathrm{w}), 1717(\mathrm{~s})$, 1600 (m), 1577 (w), 1568 (m), 1482 (m), 1464 (m), 1447 (w), 1390 (w), 1366 (m), 1225 (s), 1199 (w), $1171(\mathrm{w}), 1134$ (s), 1076 (s), 917 (m), 855 (w), 771 (m), $757(\mathrm{~m}), 715(\mathrm{~m})$.

MS: $\quad(\mathrm{EI}, 70 \mathrm{eV})$

$177\left(\mathrm{M}^{+}+1,5\right), 176(33), 148$ (25), 132 (14), 131 (100), 103 (28), 77 (27)

$\underline{R}_{f}: \quad 0.14$ (hexane/ethyl acetate, $20: 1$ )

\section{Preparation of 2-Ethenylbenzoic acid, Ethyl Ester (3f) ${ }^{7}$}

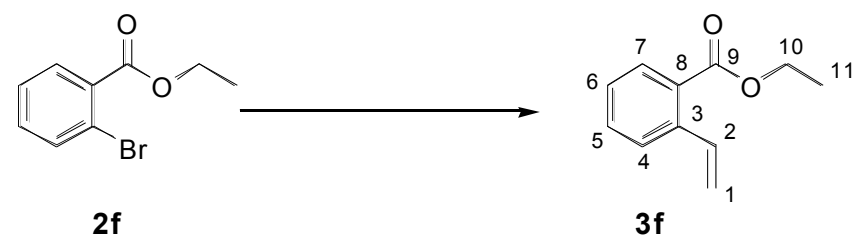

Following General Procedure V, 2-(di-t-butylphosphino)biphenyl (59.6 mg, $0.20 \mathrm{mmol}$, 0.10 equiv), palladium bromide (26.6 mg, $0.1 \mathrm{mmol}, 0.05$ equiv), a solution of 1,3,5,7tetramethyl-1,3,5,7-tetravinylcyclotetrasiloxane $(344 \mathrm{mg}, 1.0 \mathrm{mmol}, 0.5$ equiv) in THF (0.1 mL), TBAF (4 mL, $1 \mathrm{M}$ in THF, $4 \mathrm{mmol}, 2.0$ equiv), ethyl 2-bromobenzoate (458 mg, $2.0 \mathrm{mmol}$ ) were combined, and the reaction was warmed to $50{ }^{\circ} \mathrm{C}$ in an oil bath. GC analysis at $5 \mathrm{~h}$ indicated that no bromide remained, and the reaction was allowed to cool to room temperature. Diethyl ether $(10 \mathrm{~mL})$ was added and the mixture was stirred for $10 \mathrm{~min}$ at room temperature then filtered through a short pad of alumina $(5 \mathrm{~g})$. The alumina pad was washed with diethyl ether $(50 \mathrm{~mL})$, and the combined filtrates were concentrated in vacuo to afford $615 \mathrm{mg}$ of crude material. Purification by column chromatography (hexane/ethyl acetate (25:1), $\mathrm{SiO}_{2}, 120 \mathrm{~mm}$ x $30 \mathrm{~mm}$ ) and bulb-to-bulb distillation afforded $282 \mathrm{mg}(86 \%)$ of $\mathbf{3 f}$ as a clear oil.

$\underline{\text { Data for 3f }}$

bp: $\quad 82{ }^{\circ} \mathrm{C}(0.1 \mathrm{mmHg}, \mathrm{ABT})$

${ }^{1} \underline{\mathrm{H} \text { NMR: }} \quad\left(500 \mathrm{MHz}, \mathrm{CDCl}_{3}\right)$

$7.87(\mathrm{dd}, J=7.9$ and 1.3, $1 \mathrm{H}, \mathrm{HC}(7)), 7.58$ (d, $J=7.9,1 \mathrm{H}, \mathrm{HC}(4)), 7.48$ (t, $J=$ 7.9, $1 \mathrm{H}, \mathrm{HC}(5)), 7.46(\mathrm{dd}, J=17.6$ and 11.0, $1 \mathrm{H}, \mathrm{HC}(2)), 7.32$ (td, $J=7.9$ and 1.2, $1 \mathrm{H}, \mathrm{HC}(6)), 5.65\left(\mathrm{dd}, J=17.6\right.$ and 1.2, $\left.1 \mathrm{H}, \mathrm{H}_{\text {trans }} \mathrm{C}(1)\right), 5.35(\mathrm{dd}, J=10.9$ and 1.2, $\left.1 \mathrm{H}, \mathrm{H}_{\mathrm{cis}} \mathrm{C}(1)\right), 4.37$ (q, $\left.J=7.2,2 \mathrm{H}, \mathrm{HC}(10)\right), 1.39$ (t, $J=7.1,3 \mathrm{H}$, $\mathrm{HC}(11))$. 
${ }^{13} \mathrm{C} \mathrm{NMR:} \quad\left(125 \mathrm{MHz},\left(\mathrm{CDCl}_{3}\right)\right.$

167.5 (C(9)), 139.5 (C(3)), 135.9 (C(2)), 132.0 (C(7)), 130.2 (C(5)), $129.0(\mathrm{C}(8))$, 127.4 (C(4)), 127.2 (C(6)), 116.4 (C(1)), 61.0 (C(10)), 14.3 (C(11)).

IR: $\quad 3416(\mathrm{w}), 3089(\mathrm{~m}), 3067$ (m), 2982 (s), 2938 (m), 2905 (w), 2361 (w), 2339 (w), 2256 (w), 1838 (w), 1717 (s), 1626 (w), 1599 (w), 1568 (m), 1482 (m), 1447 (w), 1390 (m), 1366 (s), 1288 (s), 1254 (s), 1200 (m), 1171 (w), 1133 (s), 1076 (s), $1022(\mathrm{~m}), 990$ (m), 917 (s), 855 (w), 771 (s), $716(\mathrm{~s})$.

MS: $\quad(\mathrm{EI}, 70 \mathrm{eV})$

$177\left(\mathrm{M}^{+}+1,24\right), 176(100), 149$ (25), 148 (66), 147 (51), 132 (31), 131 (87), 130 (12), 129 (11), 120 (21), 119 (41), 105 (30), 104 (12), 103 (58), 102 (36), 91 (34), 77 (58), 76 (14), 75 (12), 74 (10), 63 (11).

$\underline{R}_{f}: \quad 0.14$ (hexane/ethyl acetate, $25: 1$ )

Preparation of 2-Ethenylnaphthalene (3g) ${ }^{6}$

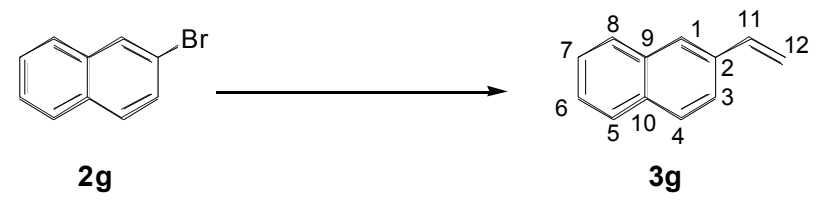

Following General Procedure V, 2-(di-t-butylphosphino)biphenyl (59.4 mg, $0.20 \mathrm{mmol}$, 0.10 equiv), palladium bromide (26.6 mg, $0.1 \mathrm{mmol}, 0.05$ equiv), a solution of 1,3,5,7tetramethyl-1,3,5,7-tetravinylcyclotetrasiloxane (344 mg, $1.0 \mathrm{mmol}, 0.5$ equiv) in THF (0.1 mL), TBAF (4 mL, $1 \mathrm{M}$ in THF, $4 \mathrm{mmol}, 2.0$ equiv) and 2-bromonaphthalene (414 mg, $2.0 \mathrm{mmol}$ ) were combined, and the reaction was warmed to $50{ }^{\circ} \mathrm{C}$ in an oil bath. $\mathrm{GC}$ analysis at $3 \mathrm{~h}$ indicated that no bromide remained, and the reaction was allowed to cool to room temperature. Diethyl ether $(10 \mathrm{~mL})$ was added and the mixture was stirred for $10 \mathrm{~min}$ at room temperature then filtered through a short pad of silica $(5 \mathrm{~g})$. The silica pad was washed with diethyl ether (50 $\mathrm{mL}$ ), and the combined filtrates were concentrated in vacuo and purified by column chromatography (pentane, $\mathrm{SiO}_{2}, 160 \mathrm{~mm}$ x $30 \mathrm{~mm}$ ) gave $249 \mathrm{mg}(81 \%)$ of $\mathbf{3 g}$ as a white solid.

Data for 3g

mp: $\quad 64-66^{\circ} \mathrm{C}$

${ }^{1}$ H NMR: $\quad\left(500 \mathrm{MHz}, \mathrm{CDCl}_{3}\right)$

7.89-7.92 (m, 3 H, HC(4), HC(5), HC(8)), 7.75 (bs, 1 H, HC(1)), 7.64 (dd, $J=8.6$ 
and 2.0, $1 \mathrm{H}, \mathrm{HC}(3)), 7.46(\mathrm{td}, J=7.1$ and 1.8, $1 \mathrm{H}, \mathrm{HC}(7)), 7.44(\mathrm{td}, J=7.1$ and 1.7, $1 \mathrm{H}, \mathrm{HC}(6)), 6.88(\mathrm{dd}, J=17.6$ and 10.9, $1 \mathrm{H}, \mathrm{HC}(11)), 5.88(\mathrm{~d}, J=17.6,1$ $\left.\mathrm{H}, \mathrm{H}_{\text {trans }} \mathrm{C}(12)\right), 5.34$ (dd, $J=10.9$ and $\left.1.4,1 \mathrm{H}, \mathrm{H}_{\text {cis }} \mathrm{C}(12)\right)$.

${ }^{13} \mathrm{C}$ NMR: $\quad\left(125 \mathrm{MHz},\left(\mathrm{CDCl}_{3}\right)\right.$

136.9 (C(11)), $135.0(\mathrm{C}(2)), 133.5$ (C(9)), 133.1 (C(10)), 128.2 (C(4)), 128.0 (C(8)), 127.7 (C(5)), 126.4 (C(1)), 126.2 (C(7)), 125.9 (C(6)), 123.2 (C(3)), 114.2 (C(12)).

IR: $\quad 3057(\mathrm{~m}), 2922$ (s), 2723 (s), 1702 (w), $1627(\mathrm{w}), 1591(\mathrm{w}), 1461$ (s), 1376 (s), $1270(\mathrm{w}), 1168(\mathrm{w}), 1124(\mathrm{w}), 986(\mathrm{~m}), 951$ (w), 904 (m), $890(\mathrm{w}), 854(\mathrm{~m}), 815$ (m), $747(\mathrm{~m}), 722(\mathrm{~m})$.

MS: $\quad(\mathrm{EI}, 70 \mathrm{eV})$

$154\left(\mathrm{M}^{+}, 100\right), 153$ (47), 152 (29), 128.1 (10), 76 (13).

$\underline{R}_{f} \quad 0.07$ (hexane/ethyl acetate, $50: 1$ )

\section{Preparation of 1-Ethenyl-2-ethylbenzene $(3 \mathrm{~h})^{8}$}

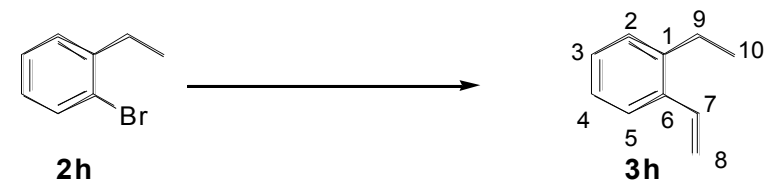

Following General Procedure V, 2-(di-t-butylphosphino)biphenyl (59.6 mg, $0.20 \mathrm{mmol}$, 0.10 equiv), palladium bromide (26.6 mg, $0.1 \mathrm{mmol}, 0.05$ equiv), a solution of 1,3,5,7tetramethyl-1,3,5,7-tetravinylcyclotetrasiloxane (344 mg, $1.0 \mathrm{mmol}, 0.5$ equiv) in THF ( $0.1 \mathrm{~mL})$, TBAF (4 mL, $1 \mathrm{M}$ in THF, $4 \mathrm{mmol}, 2.0$ equiv), 2-bromoethylbenzene (368 mg, $2.0 \mathrm{mmol}$ ) were combined, and the reaction was warmed to $50{ }^{\circ} \mathrm{C}$ in an oil bath. $\mathrm{GC}$ analysis at $17 \mathrm{~h}$ indicated that no bromide remained, and the reaction was allowed to cool to room temperature. Diethyl ether $(10 \mathrm{~mL})$ was added and the mixture was stirred for $10 \mathrm{~min}$ at room temperature then filtered through a short pad of silica $(5 \mathrm{~g})$. The silica pad was washed with diethyl ether (50 $\mathrm{mL}$ ), and the combined filtrates were concentrated in vacuo to afford $310 \mathrm{mg}$ of crude material. Purification by column chromatography (pentane, $\mathrm{SiO}_{2}, 125 \mathrm{~mm}$ x $30 \mathrm{~mm}$ ) and bulb-to-bulb distillation afforded $195 \mathrm{mg}(75 \%)$ of $\mathbf{3 h}$ as a clear oil.

Data for $\mathbf{3 h}$

bp: $\quad 65^{\circ} \mathrm{C}(10 \mathrm{mmHg}, \mathrm{ABT})$ 
${ }^{1} \underline{\text { H NMR: }} \quad\left(500 \mathrm{MHz}, \mathrm{CDCl}_{3}\right)$

7.49 (dd, $J=7.5$ and 1.5, $1 \mathrm{H}, \mathrm{HC}(5)), 7.22-7.15$ (m, $3 \mathrm{H}, \mathrm{HC}(4), \mathrm{HC}(3), \mathrm{HC}(2))$, $7.00(\mathrm{dd}, J=17.4$ and 11.0, $1 \mathrm{H}, \mathrm{HC}(7)), 5.65(\mathrm{dd}, J=17.3$ and $1.5,1 \mathrm{H}$, $\left.\mathrm{H}_{\text {trans }} \mathrm{C}(8)\right), 5.29\left(\mathrm{dd}, J=11.0\right.$ and $\left.1.5,1 \mathrm{H}, \mathrm{H}_{\text {cis }} \mathrm{C}(8)\right), 2.71$ (q, $\left.J=7.6, \mathrm{HC}(9)\right)$, $1.20(\mathrm{t}, J=7.6,1 \mathrm{H}, \mathrm{HC}(10))$.

${ }^{13} \mathrm{C}$ NMR: $\quad\left(125 \mathrm{MHz},\left(\mathrm{CDCl}_{3}\right)\right.$

$141.8(\mathrm{C}(1)), 136.4(\mathrm{C}(6)), 134.8(\mathrm{C}(7)), 128.9(\mathrm{C}(3)), 128.1(\mathrm{C}(5)), 126.3(\mathrm{C}(4))$, $125.9(\mathrm{C}(2)), 115.5(\mathrm{C}(8)), 26.5(\mathrm{C}(9)), 15.5(\mathrm{C}(10))$.

IR: $3087(\mathrm{w}), 3061(\mathrm{w}), 3016(\mathrm{w}), 2966(\mathrm{~s}), 2933(\mathrm{~m}), 2874(\mathrm{~m}), 2360(\mathrm{w}), 2341(\mathrm{w})$, 1914 (w), 1813 (w), 1625 (w), 1599 (w), 1484 (m), 1467 (w), 1452 (m), 1408 (w), $1375(\mathrm{w}), 1270(\mathrm{~s}), 1121(\mathrm{~s}), 990(\mathrm{~m}), 962(\mathrm{w}), 911$ (m), $770(\mathrm{~s})$.

MS: $\quad(E I, 70 \mathrm{eV})$

$133\left(\mathrm{M}^{+}+1,5\right), 132$ (41), 131 (16), 129 (22), 128 (11), 118 (13), 117 (100), 116 (11), 115 (35), 91 (24).

$\underline{R}_{f}: \quad 0.4$ (pentane)

\section{Preparation of 2-Ethenyl-1,3,5-trimethylbenzene (3i) ${ }^{9}$}

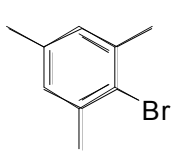

2i

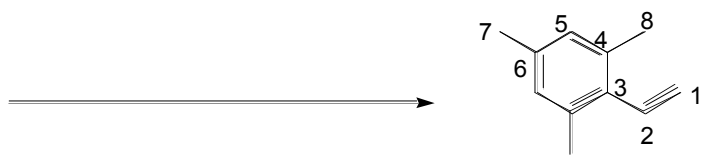

$3 \mathbf{i}$

Following General Procedure V, 2-(di-t-butylphosphino)biphenyl (59.4 mg, $0.20 \mathrm{mmol}$, 0.10 equiv), palladium bromide ( $26.6 \mathrm{mg}, 0.1 \mathrm{mmol}, 0.05$ equiv), a solution of $1,3,5,7-$ tetramethyl-1,3,5,7-tetravinylcyclotetrasiloxane ( $344 \mathrm{mg}, 1.0 \mathrm{mmol}, 0.5$ equiv) in THF $(0.1 \mathrm{~mL})$, TBAF ( $4 \mathrm{~mL}, 1 \mathrm{M}$ in THF, $4 \mathrm{mmol}, 2.0$ equiv) and 82 (398 mg, $2.0 \mathrm{mmol}$ ) were combined, and the reaction was warmed to $50{ }^{\circ} \mathrm{C}$ in an oil bath. After $48 \mathrm{~h}$, the reaction was allowed to cool to room temperature. Pentane $(10 \mathrm{~mL})$ was added and the mixture was stirred for $10 \mathrm{~min}$ at room temperature, then filtered twice through a short pad of silica $(5 \mathrm{~g})$. The silica pad was washed with pentane $(50 \mathrm{~mL})$ and the combined filtrates were concentrated in vacuo to afford $407 \mathrm{mg}$ of crude material. Purification by column chromatography (pentane (20:1), $\mathrm{SiO}_{2}, 120 \mathrm{~mm}$ x $30 \mathrm{~mm}$ ) 
and bulb-to-bulb distillation afforded $211 \mathrm{mg}$ (72\%) of $\mathbf{3 i}$ as a clear oil, containing $5 \%$ of $\mathbf{2 i}$ by ${ }^{1} \mathrm{H}-\mathrm{NMR}$ analysis.

$\underline{\text { Data for 3i }}$

bp: $\quad 60^{\circ} \mathrm{C}(1 \mathrm{mmHg}, \mathrm{ABT})$

${ }^{1} \underline{\mathrm{H} \text { NMR}}: \quad\left(500 \mathrm{MHz}, \mathrm{CDCl}_{3}\right)$

$6.91(\mathrm{~s}, 2 \mathrm{H}, \mathrm{HC}(5)), 6.71(\mathrm{dd}, J=18.0$ and 11.5, $1 \mathrm{H}, \mathrm{HC}(2)), 5.54(\mathrm{dd}, J=11.5$ and 2.1, $\left.1 \mathrm{H}, \mathrm{H}_{\mathrm{cis}} \mathrm{C}(1)\right) 5.28\left(\mathrm{dd}, J=17.9\right.$ and $\left.2.1,1 \mathrm{H}, \mathrm{H}_{\text {trans }} \mathrm{C}(1)\right), 2.32(\mathrm{~s}, 6 \mathrm{H}$, $\mathrm{HC}(8)), 2.31$ (s, $3 \mathrm{H}, \mathrm{HC}(7))$.

${ }^{13} \mathrm{C} \mathrm{NMR:} \quad\left(125 \mathrm{MHz}, \mathrm{CDCl}_{3}\right)$

136.4 (C(6)), 136.0 (C(4)), 135.2 (C(5)), 135.0 (C(3)), 128.7 (C(2)), 119.3 (C(1)), $21.1(\mathrm{C}(7)), 21.0(\mathrm{C}(8))$.

IR: 3084 (m), 2999 (s), 2971 (s), 2948 (s), 2918 (s), 2859 (s), 2732 (w), 1842 (w), 1726 (w), 1630 (s), 1612 (s), 1567 (m), 1481 (s), 1442 (s), 1402 (m), 1376 (s), 1292 (s), 1206 (w), 1175 (w), 1147 (w), 1029 (s), 1015 (s), 994 (s), 919 (s), 850 (s), $754(\mathrm{~m}), 713(\mathrm{w}), 697(\mathrm{w}), 687(\mathrm{w}), 664(\mathrm{w})$.

MS: $\quad(\mathrm{EI}, 70 \mathrm{eV})$

147 (M+1, 17), $146(\mathrm{M}+, 100), 145$ (14), 131 (55), 129 (11), 115 (13), 91 (13).

$\underline{R}_{f}: \quad 0.70$ (pentane)

\section{Preparation of 1-Ethenyl-2-methoxybenzene (3j)}

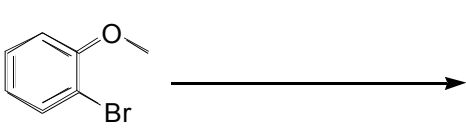

2j

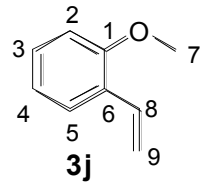

3

Following General Procedure V, 2-(di-t-butylphosphino)biphenyl (59.6 mg, $0.20 \mathrm{mmol}$, 0.10 equiv), palladium bromide (26.6 mg, $0.1 \mathrm{mmol}, 0.05$ equiv), a solution of 1,3,5,7tetramethyl-1,3,5,7-tetravinylcyclotetrasiloxane (344 mg, $1.0 \mathrm{mmol}, 0.5$ equiv) in THF $(0.1 \mathrm{~mL})$, TBAF (4 mL, $1 \mathrm{M}$ in THF, $4 \mathrm{mmol}, 2.0$ equiv), 2-bromoanisole (374 mg, $2.0 \mathrm{mmol}$ ) were combined, and the reaction was warmed to $50{ }^{\circ} \mathrm{C}$ in an oil bath. $\mathrm{GC}$ analysis at $10 \mathrm{~h}$ indicated that no bromide remained, and the reaction was allowed to cool to room temperature. Diethyl ether $(10 \mathrm{~mL})$ was added and the mixture was stirred for $10 \mathrm{~min}$ at room temperature then filtered through a short pad of silica $(5 \mathrm{~g})$. The silica pad was washed with diethyl ether (50 
$\mathrm{mL}$ ), and the combined filtrates were concentrated in vacuo to afford $297 \mathrm{mg}$ of crude material. Purification by column chromatography (pentane/ether (100:1), $\mathrm{SiO}_{2}, 120 \mathrm{~mm}$ x $30 \mathrm{~mm}$ ) and bulb-to-bulb distillation afforded $214 \mathrm{mg}(80 \%)$ of $\mathbf{3 j}$ as a clear oil.

\section{Data for 3j}

bp: $\quad 80{ }^{\circ} \mathrm{C}(5 \mathrm{mmHg}, \mathrm{ABT})$

${ }^{1} \underline{\mathrm{H} N M R}: \quad\left(500 \mathrm{MHz}, \mathrm{CDCl}_{3}\right)$

$7.48(\mathrm{dd}, J=7.7$ and 1.7, $1 \mathrm{H}, \mathrm{HC}(3)), 7.27(\mathrm{td},=8.4$ and 1.7, $1 \mathrm{H}, \mathrm{HC}(5), 7.06$ (dd, $J=17.7$ and 11.1, $1 \mathrm{H}, \mathrm{HC}(8)), 6.95(\mathrm{td}, J=7.5$ and 1.1, $1 \mathrm{H}, \mathrm{HC}(4)), 6.88$ $(\mathrm{d}, J=8.1,1 \mathrm{H}, \mathrm{HC}(6)), 5.75\left(\mathrm{dd}, J=17.6\right.$ and $\left.1.5, \mathrm{H}_{\text {trans }} \mathrm{C}(9)\right), 5.28(\mathrm{dd}, J=11.2$ and $\left.1.5,1 \mathrm{H}, \mathrm{H}_{\mathrm{cis}} \mathrm{C}(9)\right), 3.86(\mathrm{~s}, 3 \mathrm{H}, \mathrm{HC}(7))$.

${ }^{13} \mathrm{C} \mathrm{NMR:} \quad\left(125 \mathrm{MHz}, \mathrm{CDCl}_{3}\right)$

156.7 (C(1)), $131.6(\mathrm{C}(8)), 128.8$ (C(5)), $126.7(\mathrm{C}(2)), 126.5(\mathrm{C}(3)), 120.6(\mathrm{C}(4))$, 114.1 (C(6)), 110.8 (C(9)), 55.4 (C(7)).

MS: $\quad(\mathrm{EI}, 70 \mathrm{eV})$

$135\left(\mathrm{M}^{+}+1,38\right), 134$ (100), 121 (17), 119 (71), 118 (17), 105 (11), 97 (32), 92 (14), 91 (91), 90 (10), 85 (29), 78 (16), 77 (20), 73 (16), 65 (19), 63 (12), 59 (13).

$\underline{R}_{f} \quad 0.18$ (hexane/ethyl acetate. $\left.50: 1\right)$

\section{Preparation of 4-Ethenylbenzenemethanol (3k) ${ }^{10}$}

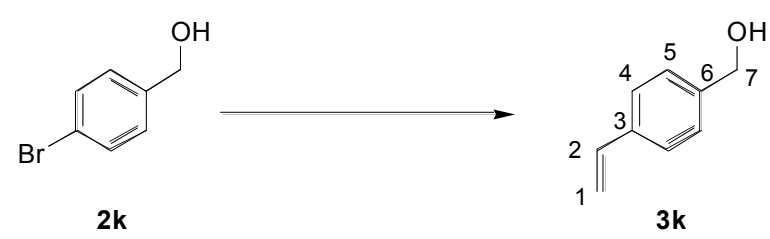

Following General Procedure V, 2-(di-t-butylphosphino)biphenyl (59.6 mg, $0.20 \mathrm{mmol}$, 0.10 equiv), palladium bromide (26.6 mg, $0.1 \mathrm{mmol}, 0.05$ equiv), a solution of 1,3,5,7tetramethyl-1,3,5,7-tetravinylcyclotetrasiloxane (344 mg, $1.0 \mathrm{mmol}, 0.5$ equiv) in THF $(0.1 \mathrm{~mL})$, TBAF (4 mL, 1 M in THF, 4 mmol, 2.0 equiv), 4-bromobenzyl alcohol (374 mg, $2.0 \mathrm{mmol}$ ) were combined, and the reaction was warmed to $50{ }^{\circ} \mathrm{C}$ in an oil bath. $\mathrm{GC}$ analysis at $14 \mathrm{~h}$ indicated that no bromide remained, and the reaction was allowed to cool to room temperature. Diethyl ether $(10 \mathrm{~mL})$ was added and the mixture was stirred for $10 \mathrm{~min}$ at room temperature then filtered through a short pad of silica $(5 \mathrm{~g})$. The silica pad was washed with diethyl ether (50 $\mathrm{mL}$ ), and the combined filtrates were concentrated in vacuo and purified by column 
chromatography (hexane/ethyl acetate (4:1), $\mathrm{SiO}_{2}, 120 \mathrm{~mm}$ x $30 \mathrm{~mm}$ ) and bulb-to-bulb distillation afforded $145 \mathrm{mg}(54 \%)$ of $3 \mathbf{k}$ as a clear oil.

$\underline{\text { Data for 3k }}$

bp: $\quad 120^{\circ} \mathrm{C}(0.1 \mathrm{mmHg}, \mathrm{ABT})$

${ }^{1} \underline{\mathrm{H} \mathrm{NMR}}: \quad\left(500 \mathrm{MHz}, \mathrm{CDCl}_{3}\right)$

$7.40(\mathrm{~d}, J=7.9,2 \mathrm{H}, \mathrm{HC}(4)), 7.31$ (d, $J=7.9,2 \mathrm{H}, \mathrm{HC}(5)), 6.72(\mathrm{dd}, J=17.6$ and 10.7, $1 \mathrm{H}, \mathrm{HC}(2)), 5.75\left(\mathrm{~d}, J=17.6,1 \mathrm{H}, \mathrm{H}_{\text {trans }} \mathrm{C}(1)\right), 5.25(\mathrm{~d}, J=10.9,1 \mathrm{H}$, $\left.\mathrm{H}_{\mathrm{cis}} \mathrm{C}(1)\right), 4.64$ (s, $\left.2 \mathrm{H}, \mathrm{HC}(7)\right), 1.94$ (s, $\left.1 \mathrm{H},-\mathrm{OH}\right)$.

${ }^{13} \mathrm{C}$ NMR: $\quad\left(125 \mathrm{MHz},\left(\mathrm{CDCl}_{3}\right)\right.$ 140.7 (C(6)), 137.2 (C(3)), 136.7 (C(2)), 127.4 (C(4)), 126.6 (C(5)), $114.1(\mathrm{C}(1))$, $65.3(\mathrm{C}(7))$.

IR: $\quad 3338$ (bs), $3087(\mathrm{~m}), 3051$ (m), 3022 (m), 3006 (m), 2928 (w), 2873 (m), 2360 (w), $2342(\mathrm{w}), 1908(\mathrm{w}), 1818(\mathrm{w}), 1629$ (s), 1569 (m), 1512 (s), 1454 (w), 1406 (s), $1367(\mathrm{w}), 1316(\mathrm{w}), 1288(\mathrm{w}), 1211$ (m), 1115 (m), 1024 (s), 1013 (s), 991 (s), $947(\mathrm{w}), 908(\mathrm{~s}), 847(\mathrm{~s}), 824(\mathrm{~s}), 718(\mathrm{~m})$.

MS: (EI, 70eV)

$135\left(\mathrm{M}^{+}+1,11\right), 134$ (97), 133 (37), 117 (19), 115 (17), 108 (13), 107 (26), 105 (100), 91 (36), 79 (74), 77 (65), 63 (17).

$\underline{R_{f}} \quad 0.20$ (hexane/ethyl acetate, $4: 1$ )

\section{Preparation of 1-Ethenyl-2-nitrobenzene (3I) ${ }^{11}$}

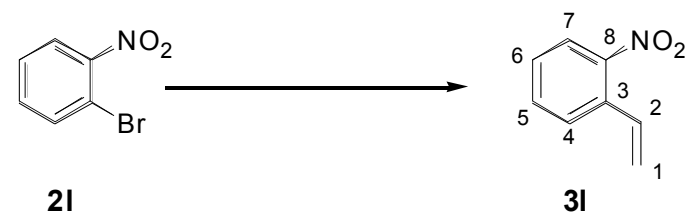

Following General Procedure V, 2-(di-t-butylphosphino)biphenyl (59.6 mg, $0.20 \mathrm{mmol}$, 0.10 equiv), palladium bromide (26.6 mg, $0.1 \mathrm{mmol}, 0.05$ equiv), a solution of 1,3,5,7tetramethyl-1,3,5,7-tetravinylcyclotetrasiloxane $(344 \mathrm{mg}, 1.0 \mathrm{mmol}, 0.5$ equiv) in THF $(0.1 \mathrm{~mL})$, TBAF (4 mL, $1 \mathrm{M}$ in THF, 4 mmol, 2.0 equiv), 2-bromonitrobenzene (404 mg, $2.0 \mathrm{mmol}$ ) were combined, and the reaction was warmed to $50{ }^{\circ} \mathrm{C}$ in an oil bath. $\mathrm{GC}$ analysis at $2 \mathrm{~h}$ indicated that no bromide remained, and the reaction was allowed to cool to room temperature. Diethyl ether $(10 \mathrm{~mL})$ was added and the mixture was stirred for $10 \mathrm{~min}$ at room temperature then filtered 
through a short pad of alumina $(5 \mathrm{~g})$. The alumina pad was washed with diethyl ether $(50 \mathrm{~mL})$, and the combined filtrates were concentrated in vacuo to afford $534 \mathrm{mg}$ of crude material. Purification by column chromatography (hexane/ethyl acetate (25:1), $\mathrm{SiO}_{2}, 140 \mathrm{~mm}$ x $30 \mathrm{~mm}$ ) and Kugelrohr distillation afforded $270 \mathrm{mg}(91 \%)$ of $\mathbf{3 I}$ as a yellow oil.

Data for 31

bp: $\quad 65^{\circ} \mathrm{C}(0.1 \mathrm{mmHg}, \mathrm{ABT})$

${ }^{1}$ H NMR: $\quad\left(500 \mathrm{MHz}, \mathrm{CDCl}_{3}\right)$

$7.92(\mathrm{dd}, J=8.3$, and 1.2, $1 \mathrm{H}, \mathrm{HC}(7)), 7.62(\mathrm{dd}, J=7.8$, and 1.4, $1 \mathrm{H}, \mathrm{HC}(4))$, $7.59(\mathrm{td}, J=8.1$ and 1.1, $1 \mathrm{H}, \mathrm{HC}(5)), 7.41(\mathrm{td}, J=8.3$ and 1.5, $1 \mathrm{H}, \mathrm{HC}(6)), 7.17$ $(\mathrm{dd}, J=17.4$ and 10.9, $1 \mathrm{H}, \mathrm{HC}(2)), 5.74\left(\mathrm{~d}, J=17.4,1 \mathrm{H}, \mathrm{H}_{\text {trans }} \mathrm{C}(1)\right), 5.48(\mathrm{~d}, J=$ $\left.10.9,1 \mathrm{H}, \mathrm{H}_{\mathrm{cis}} \mathrm{C}(1)\right)$.

${ }^{13} \mathrm{C}$ NMR: $\quad\left(125 \mathrm{MHz}, \mathrm{CDCl}_{3}\right)$

$133.5(\mathrm{C}(3)), 133.4(\mathrm{C}(7)), 132.7(\mathrm{C}(2)), 128.7(\mathrm{C}(5)), 128.6(\mathrm{C}(4)), 127.3(\mathrm{C}(8))$, 124.6 (C(6)), 119.2 (C(1)).

IR: $\quad 3094$ (w), 3071 (m), 2958 (s), 2927 (s), 2871 (s), 2859 (s), 2375 (w), 1943 (w), $1855(\mathrm{w}), 1736$ (w), 1608 (m), 1570 (s), 1526 (s), 1467 (m), 1444 (w), 1413 (w), 1349 (a), 1302 (m), 1269 (w), 1078 (bs), 982 (s), 857 (s), 783 (s), 760 (s), 709 (m), $668(\mathrm{~m})$.

MS: $\quad(\mathrm{EI}, 70 \mathrm{eV})$

$150\left(\mathrm{M}^{+}+1,7\right), 149\left(\mathrm{M}^{+}, 4\right), 132$ (50), 121 (16), 120 (59), 104 (21), 103 (14), 102 (23), 93 (21), 92 (35), 91 (100), 89 (11), 78 (11), 77 (66), 76 (18), 75 (15), 74 (14), 66 (18), 65 (57).

$\underline{R}_{f}: \quad 0.17$ (hexane/ethyl acetate, $25: 1$ ) 
Preparation of N-(4-Ethenylphenyl)-acetamide $(3 \mathrm{~m})^{12}$

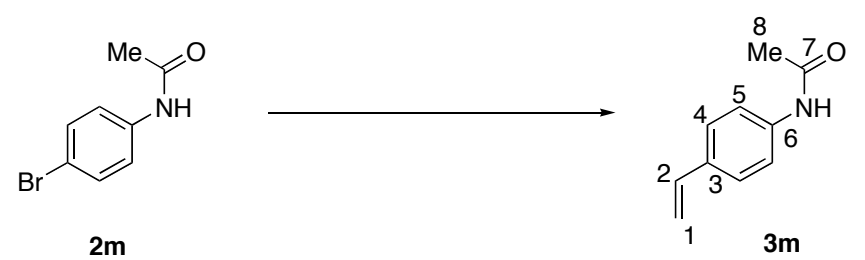

Following General Procedure V, 2-(di-t-butylphosphino)biphenyl (59.4 mg, $0.20 \mathrm{mmol}$, 0.10 equiv), palladium bromide (26.6 mg, $0.1 \mathrm{mmol}, 0.05$ equiv), a solution of 1,3,5,7tetramethyl-1,3,5,7-tetravinylcyclotetrasiloxane $(344 \mathrm{mg}, 1.0 \mathrm{mmol}, 0.5$ equiv) in THF $(0.1 \mathrm{~mL})$, TBAF (4 mL, $1 \mathrm{M}$ in THF, $4 \mathrm{mmol}, 2.0$ equiv) and $\mathbf{2 m}$ (428 mg, $2.0 \mathrm{mmol}$ ) were combined, and the reaction was warmed to $50{ }^{\circ} \mathrm{C}$ in an oil bath. At $12 \mathrm{~h}$, the reaction was allowed to cool to room temperature. Diethyl ether $(10 \mathrm{~mL})$ was added and the mixture was stirred for $10 \mathrm{~min}$ at room temperature, after which the mixture was partitioned between dichloromethane $(100 \mathrm{~mL})$ and an aqueous solution of 2-(N,N-dimethylamino)ethanethiol $(1 \%, 100 \mathrm{~mL})$, washed with water $(100 \mathrm{~mL})$, and back extracted with ethyl acetate. The combined organics were combined, dried over $\mathrm{Na}_{2} \mathrm{SO}_{4}$, filtered, and concentrated in vacuo to afford $654 \mathrm{mg}$ of crude material. Purification by column chromatography (ethyl acetate/hexane (1:1), $\mathrm{SiO}_{2}, 120 \mathrm{~mm}$ x $30 \mathrm{~mm}$ ) and recrystallization from isopropanol afforded $249 \mathrm{mg}(77 \%)$ of $\mathbf{3 m}$ as a white solid.

\section{$\underline{\text { Data for 3m }}$}

mp: $\quad 133-134{ }^{\circ} \mathrm{C}$

${ }^{1} \underline{\mathrm{H} N M R}: \quad\left(500 \mathrm{MHz}, \mathrm{CDCl}_{3}\right)$

$7.47(\mathrm{~d}, J=8,1,2 \mathrm{H}, \mathrm{HC}(4)), 7.36$ (d, $J=8.5,1 \mathrm{H}, \mathrm{HC}(5)), 7.20$ (bs, $1 \mathrm{H},-\mathrm{NH})$ )

$6.67(\mathrm{dd}, J=17.6$ and 10.8, $1 \mathrm{H}, \mathrm{HC}(2)), 5.68\left(\mathrm{~d}, J=17.6,1 \mathrm{H}, \mathrm{HC}_{\text {trans }}(1)\right), 5.19$ $\left(\mathrm{d}, J=10.8,1 \mathrm{H}, \mathrm{HC}_{\text {cis }}(1)\right), 2.18(\mathrm{~s}, 3 \mathrm{H}, \mathrm{HC}(8))$.

${ }^{13} \mathrm{C} \mathrm{NMR}: \quad\left(125 \mathrm{MHz},\left(\mathrm{CDCl}_{3}\right)\right.$

168.7 (C(7)), 137.7 (C(6)), 136.3 (C(2)), 133.9 (C(3)), 127.0 (C(4)), 120.1 (C(5)), $113.2(\mathrm{C}(1)), 24.7(\mathrm{C}(8))$.

IR: $\quad 3288(\mathrm{~m}), 3178(\mathrm{w}), 3108(\mathrm{w}), 1660(\mathrm{~m}), 1626(\mathrm{~m}), 1592(\mathrm{w}), 1513(\mathrm{w}), 1401$ (m), $1323(\mathrm{w}), 1266(\mathrm{w}), 994(\mathrm{w}), 905(\mathrm{w}), 842(\mathrm{w})$.

MS: $\quad(\mathrm{EI}, 70 \mathrm{eV})$

$$
\text { 162(M+1, 5), } 161(\mathrm{M}+, 45), 120 \text { (11), } 119 \text { (100), } 118 \text { (24), } 91 \text { (12). }
$$

$\underline{R}_{f}: \quad 0.27$ (hexane/ethyl acetate, $\left.1: 1\right)$ 


\section{Preparation of 2-Ethenyl- $N, N$-dimethylbenzenamine $(3 n)^{13}$}
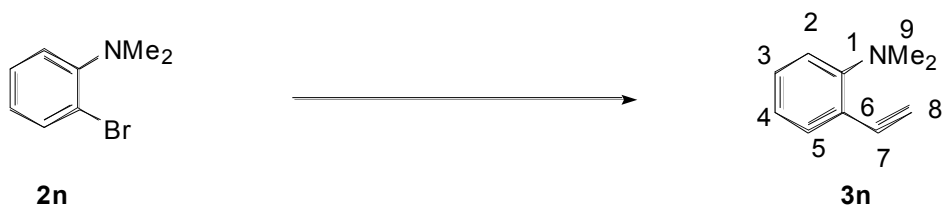

Following General Procedure V, 2-(di-t-butylphosphino)biphenyl (59.4 mg, $0.20 \mathrm{mmol}$, 0.10 equiv), palladium bromide (26.6 mg, $0.1 \mathrm{mmol}, 0.05$ equiv), a solution of 1,3,5,7tetramethyl-1,3,5,7-tetravinylcyclotetrasiloxane (344 mg, $1.0 \mathrm{mmol}, 0.6$ equiv) in THF $(0.1 \mathrm{~mL})$, TBAF ( $4 \mathrm{~mL}, 1 \mathrm{M}$ in THF, $4 \mathrm{mmol}, 2.5$ equiv) and $N, N$-dimethyl-2-bromoaniline (325 mg, 1.6 mmol) were combined, and the reaction was warmed to $50{ }^{\circ} \mathrm{C}$ in an oil bath. After $24 \mathrm{~h}$, the reaction was allowed to cool to room temperature. Diethyl ether $(10 \mathrm{~mL})$ was added and the mixture was stirred for $10 \mathrm{~min}$ at room temperature then filtered through a short pad of silica (5 g). The silica pad was washed with diethyl ether $(50 \mathrm{~mL})$, and the combined filtrates were concentrated in vacuo affording $346 \mathrm{mg}$. Purification by column chromatography (hexane/ethyl acetate (100:1), $\mathrm{SiO}_{2}, 120 \mathrm{~mm}$ x $30 \mathrm{~mm}$ ) followed by bulb-to-bulb distillation afforded $169 \mathrm{mg}$ of a mixture of $\mathbf{3 n}$ to the dimethylaniline $\left(10: 1\right.$ by $\left.{ }^{1} \mathrm{H}-\mathrm{NMR}\right)$ as a clear oil.

\section{$\underline{\text { Data for 3n }}$}

bp: $\quad 65-70{ }^{\circ} \mathrm{C}(0.5 \mathrm{~mm} \mathrm{Hg}, \mathrm{ABT})$

${ }^{1}$ H NMR: $\quad\left(500 \mathrm{MHz}, \mathrm{CDCl}_{3}\right)$

$7.49(\mathrm{dd}, J=7.6$ and 1.2, $1 \mathrm{H}, \mathrm{HC}(5)), 7.29-7.24$ (m, $1 \mathrm{H}, \mathrm{HC}(3)), 7.11-7.01$ (m, 3 $\mathrm{H}, \mathrm{HC}(7), \mathrm{HC}(2) . \mathrm{HC}(4)), 5.70\left(\mathrm{dd}, J=17.8\right.$ and 1.4, $\left.1 \mathrm{H}, \mathrm{HC}_{\text {trans }}(8)\right), 5.27$ (dd, $J$ $=11.0$ and $\left.1.5,1 \mathrm{H}, \mathrm{HC}_{\mathrm{cis}}(8)\right), 2.75(\mathrm{~s}, 3 \mathrm{H}, \mathrm{HC}(9))$.

${ }^{13} \mathrm{C}$ NMR: $\quad\left(125 \mathrm{MHz},\left(\mathrm{CDCl}_{3}\right)\right.$

135.1 (C(7)), 132.0 (C(1)), 129.3 (C(6)), 128.5 (C(3)), 127.1 (C(4)), $122.5(\mathrm{C}(5))$, $118.2(\mathrm{C}(2)), 113.4(\mathrm{C}(8)), 44.8(\mathrm{C}(9))$.

IR: $\quad 3440$ (w), 3083 (w), 3064 (w), 3027 (w), 2980 (m), 2940 (m), 2863 (m), 2829 (m), 2781 (m), 1902 (w), 1821 (w), 1624 (m), 1596 (s), 1507 (m), 1487 (s), 1453 (s), $1431(\mathrm{w}), 1411(\mathrm{w}), 1316$ (s), 1190 (m), 1156 (m), 1146 (m), 1097 (w), 1057 (w), $1022(\mathrm{w}), 1005(\mathrm{~m}), 948(\mathrm{~s}), 906(\mathrm{~s}), 800(\mathrm{w}), 757(\mathrm{~s}), 716(\mathrm{w}), 691(\mathrm{w})$.

MS: $\quad(\mathrm{EI}, 70 \mathrm{eV})$

$148\left(\mathrm{M}^{+}+1,33\right), 147(\mathrm{M}+, 100), 146$ (17), 133 (17), 132 (87), 131 (14), 130.1 (16), $118(12), 117(21)$. 


\section{$\underline{R}_{f}: \quad 0.37$ (hexane/ethyl acetate, $50: 1$ )}

\section{Preparation of 3-Ethenylquinoline (3o) ${ }^{14}$}

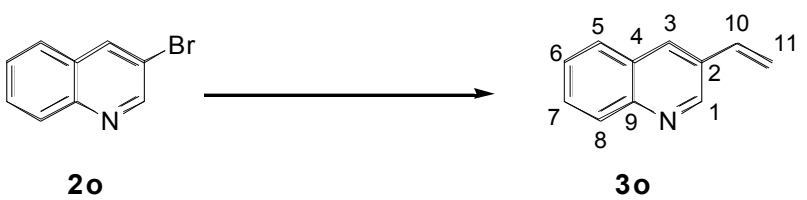

Following General Procedure V, 2-(di-t-butylphosphino)biphenyl (59.4 mg, $0.20 \mathrm{mmol}$, 0.10 equiv), palladium bromide (26.6 mg, $0.1 \mathrm{mmol}, 0.05$ equiv), a solution of 1,3,5,7tetramethyl-1,3,5,7-tetravinylcyclotetrasiloxane $(344 \mathrm{mg}, 1.0 \mathrm{mmol}, 0.5$ equiv) in THF $(0.1 \mathrm{~mL})$, TBAF (4 mL, $1 \mathrm{M}$ in THF, $4 \mathrm{mmol}, 2.0$ equiv) and 3-bromoquinoline (416 mg, $2.0 \mathrm{mmol}$ ) were combined, and the reaction was warmed to $50{ }^{\circ} \mathrm{C}$ in an oil bath. At $3 \mathrm{~h}$, the reaction was allowed to cool to room temperature. Diethyl ether $(10 \mathrm{~mL})$ was added and the mixture was stirred for 10 min at room temperature then filtered through a short pad of silica $(5 \mathrm{~g})$. The silica pad was washed with diethyl ether $(50 \mathrm{~mL})$, and the combined filtrates were concentrated in vacuo to afford $542 \mathrm{mg}$ of crude material. Purification by column chromatography (hexane/ethyl acetate (4:1), $\left.\mathrm{SiO}_{2}, 140 \mathrm{~mm} \times 30 \mathrm{~mm}\right)$ and bulb-to-bulb distillation afforded $278 \mathrm{mg}(89 \%)$ of $3 \mathbf{0}$ as a clear oil.

\section{Data for 30}

bp: $\quad 120^{\circ} \mathrm{C}(0.1 \mathrm{mmHg}, \mathrm{ABT})$

${ }^{1} \underline{\mathrm{H} \mathrm{NMR}}: \quad\left(500 \mathrm{MHz}, \mathrm{CDCl}_{3}\right)$

$9.02(\mathrm{~d}, J=1.9,1 \mathrm{H}, \mathrm{HC}(1)), 8.08(\mathrm{~d}, J=8.5,1 \mathrm{H}, \mathrm{HC}(8)), 8.07$ (d, $J=2.5,1 \mathrm{H}$, $\mathrm{HC(3))} 7.79(\mathrm{~d}, J=8.3,1 \mathrm{H}, \mathrm{HC}(5)), 7.67$ (t, $J=7.6,1 \mathrm{H}, \mathrm{HC}(6)), 7.53$ (t, $J=$ 7.8, $1 \mathrm{H}, \mathrm{HC}(7)), 6.86(\mathrm{dd}, J=17.6$ and 11.0, $1 \mathrm{H}, \mathrm{HC}(10)), 5.98(\mathrm{~d}, J=17.5,1$ $\left.\mathrm{H}, \mathrm{H}_{\text {trans }} \mathrm{C}(11)\right), 5.46\left(\mathrm{~d}, J=11.0,1 \mathrm{H}, \mathrm{H}_{\mathrm{cis}} \mathrm{C}(11)\right)$.

${ }^{13} \mathrm{C}$ NMR: $\quad\left(125 \mathrm{MHz},\left(\mathrm{CDCl}_{3}\right)\right.$ 149.0 (C(1)), 147.4 (C(9)), 133.7 (C(10)), 130.4 (C(3)), 129.4 (C(8)), 129.1 (C(7)), 128.0 (C(4)), 127.9 (C(5)), $127.0(\mathrm{C}(6)), 116.4$ (C(11)).

IR: $\quad 3385(\mathrm{~m}), 3088(\mathrm{~m}), 3065$ (m), $2291(\mathrm{w}), 1958$ (w), $1839(\mathrm{w}), 1701(\mathrm{w}), 1633$ (m), 1618 (m), 1570 (m), 1494 (s), 1462 (w), 1429 (w), 1413 (w), 1370 (s), 1328 (w), $1298(w), 1233(\mathrm{w}), 1199(\mathrm{w}), 1126(\mathrm{~s}), 1055(\mathrm{w}), 1024(\mathrm{~m}), 988(\mathrm{~s}), 976(\mathrm{~s})$, $957(\mathrm{w}), 910(\mathrm{~s}), 861(\mathrm{~m}), 787(\mathrm{~s}), 753(\mathrm{~s})$. 
MS: $\quad(\mathrm{EI}, 70 \mathrm{eV})$

$$
156\left(\mathrm{M}^{+}+1,15\right), 155 \text { (100), } 154 \text { (44), } 128 \text { (12) 127(15). }
$$

$\underline{R}_{f}: \quad 0.28$ (hexane/ethyl acetate, $4: 1$ )

\section{References:}

(1) Dent, W.T.; Long, R.; Wilkinson, J. J. Chem. Soc. 1964, 1585-1588.

(2) Ukai, T., Kawazura, H.; Ishii, Y. J. Organomet. Chem. 1974, 65, 253-266.

(3) Raiford, L. C.; Taft, R.; Lankelma, H. P. J. Am. Chem. Soc. 1924, 46, 2051-2057.

(4) Echavarren, A. M.; Stille, J. K. J. Am. Chem. Soc. 1987, 109, 5478-5486.

(5) Katritzky, A. R.; Hitchings, G. J.; King, R. W.; Zhu, D. W. Magn. Resn. Chem. 1990, 29, 2-8.

(6) Littke, A. F.; Schwarz, L.; Fu, G. C. J. Am. Chem. Soc. 2002, 124, 6343-6348.

(7) Denmark, S. E.; Wang, Z. Synthesis 2000, 999-1003.

(8) Franz, J. A.; Barrows, R. D.; Camaioni, D. M. J. Am. Chem. Soc. 1984, 106, 39643967.

(9) Lando, V. R.; Monteiro, A. L. Org. Lett., 2003, 5, 2891-2894.

(10) Abramo, J. G.; Chapin, E. C. J. Org. Chem. 1961, 26, 2671-2673.

(11) Shabarov, Y. S.; Mochalov, S. S.; Oretskaya, T. S.; Karpova, V. V. J. Organomet. Chem. 1978, 150, 7-20.

(12) Zhou, J.-C.; Wyler, H. Helv. Chem. Acta. 1999, 82, 1122-1134.

(13) Cooper, M. K.; Yanuk, D. W. J. Organomet. Chem. 1974, 74, C11-C13.

(14) Peyroux, E.; Berthiol, F.; Doucet, H.; Santelli, M. Eur. J. Org. Chem. 2004, 10751082. 


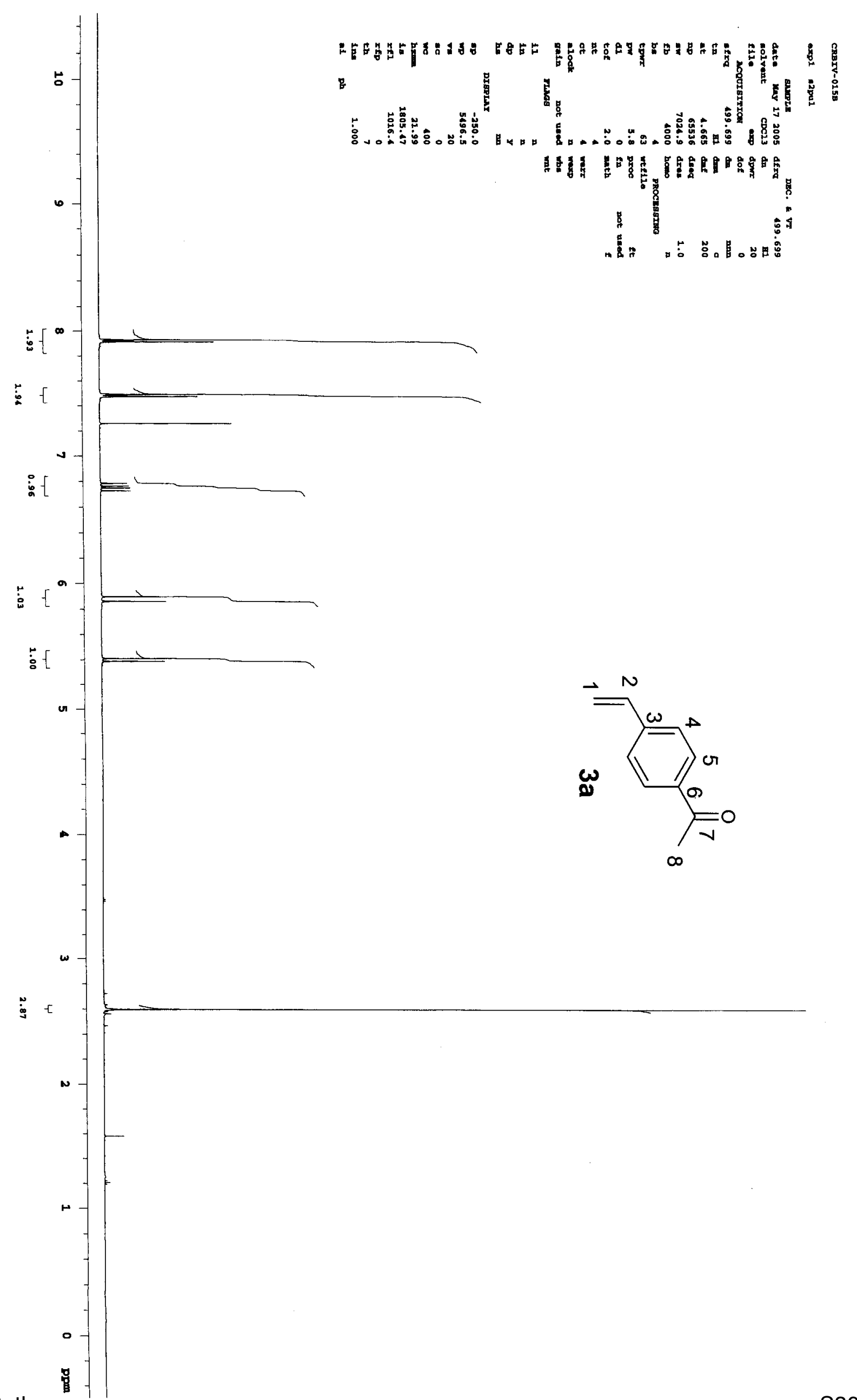




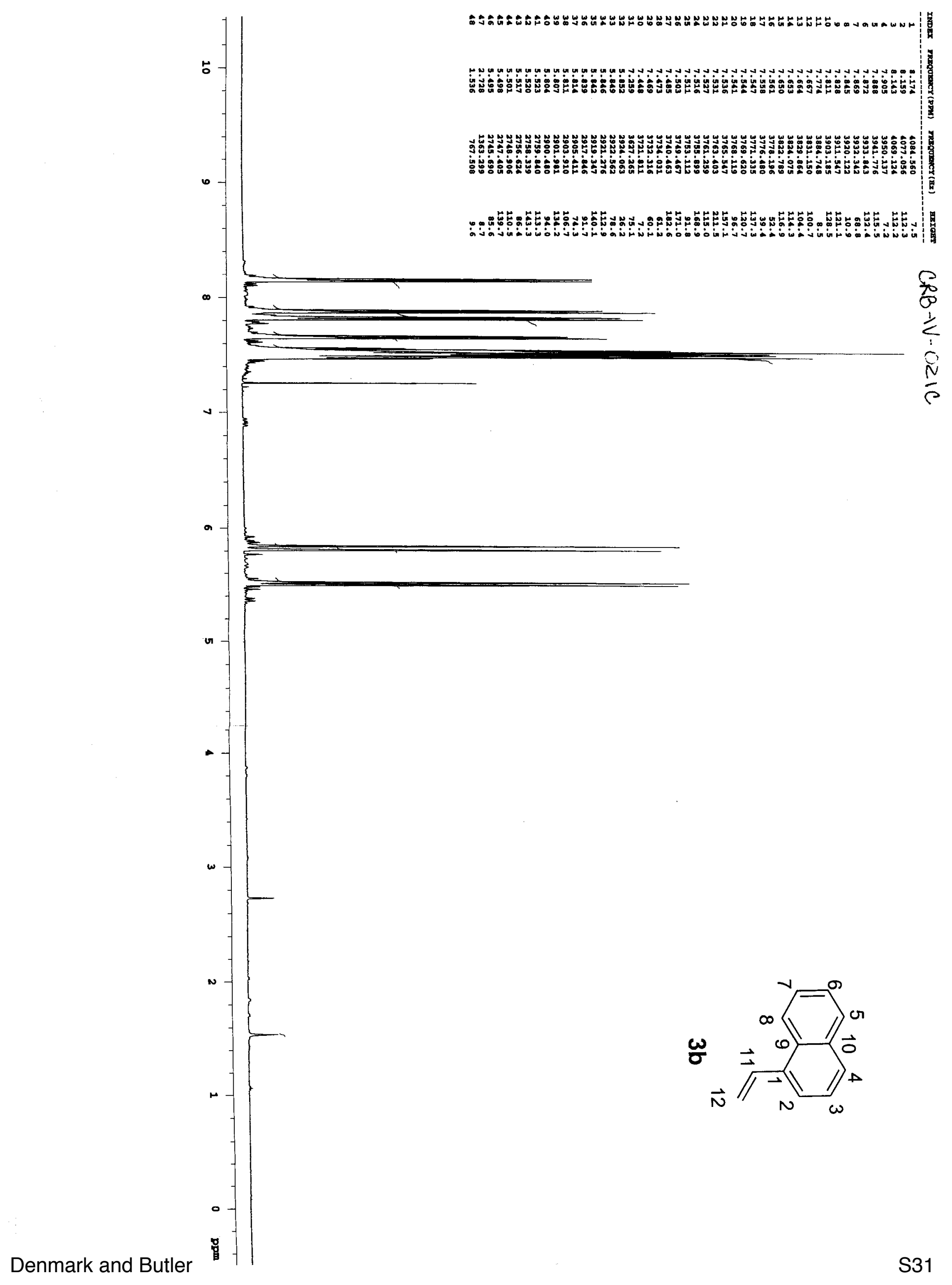




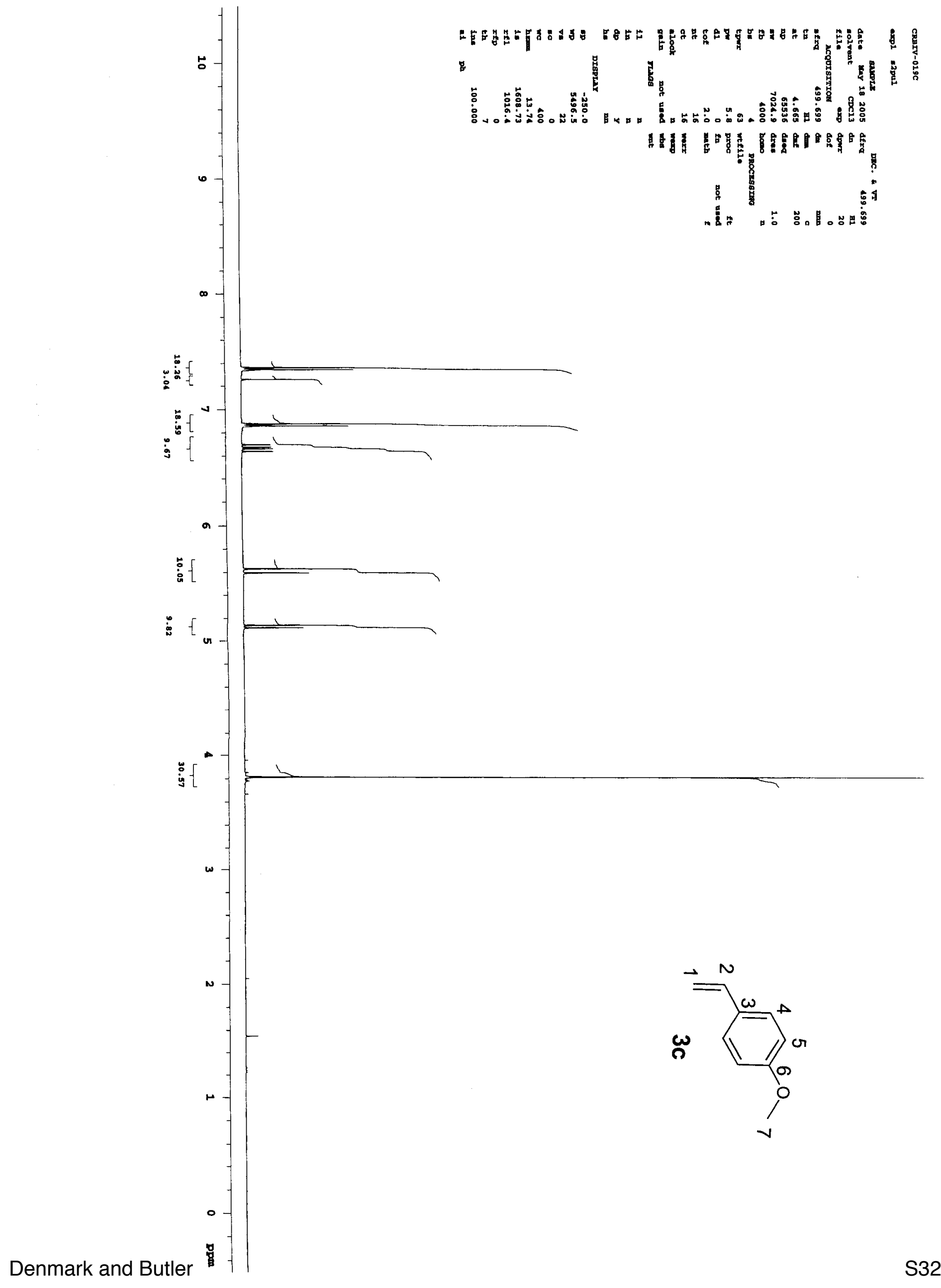




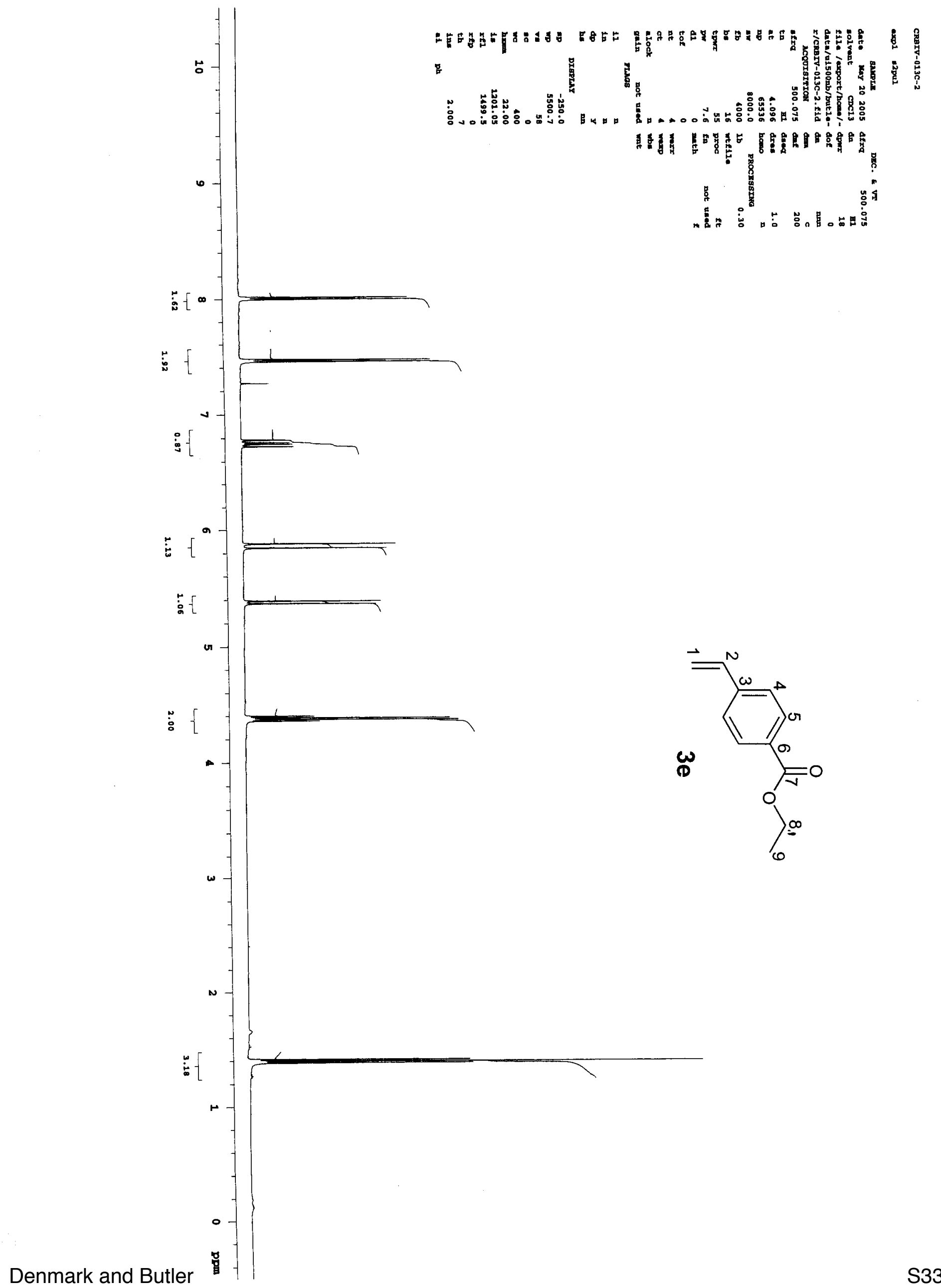




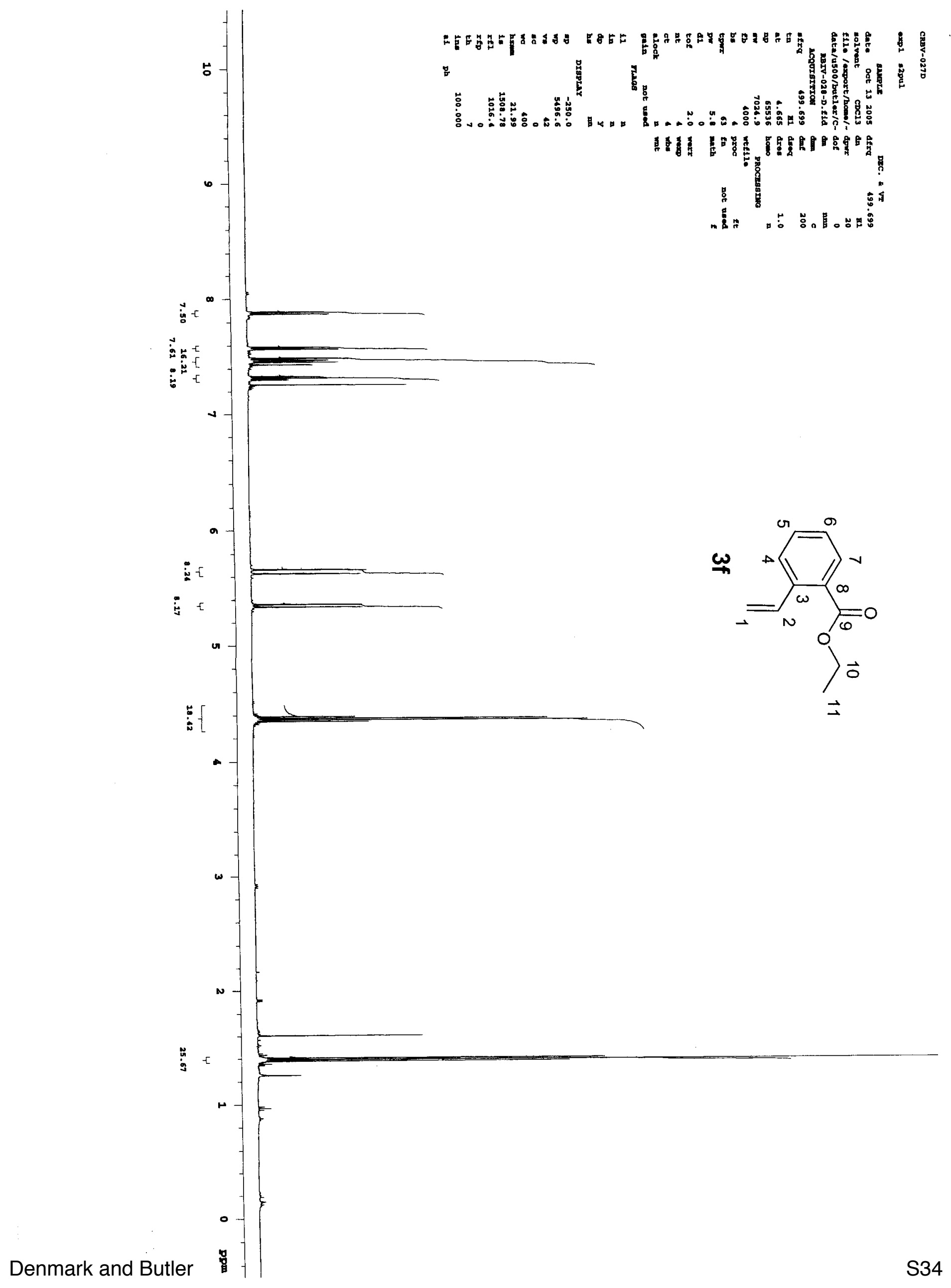




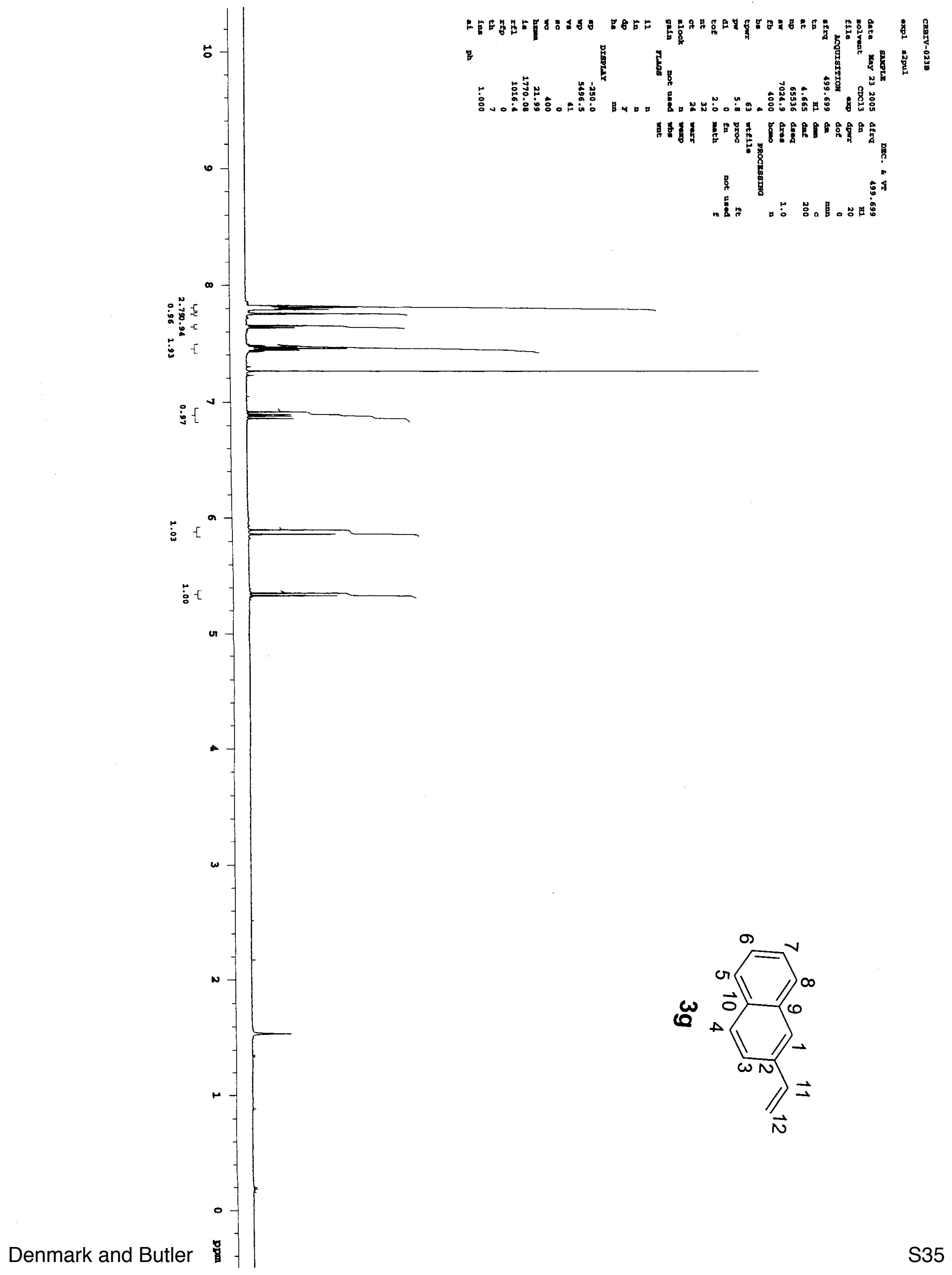




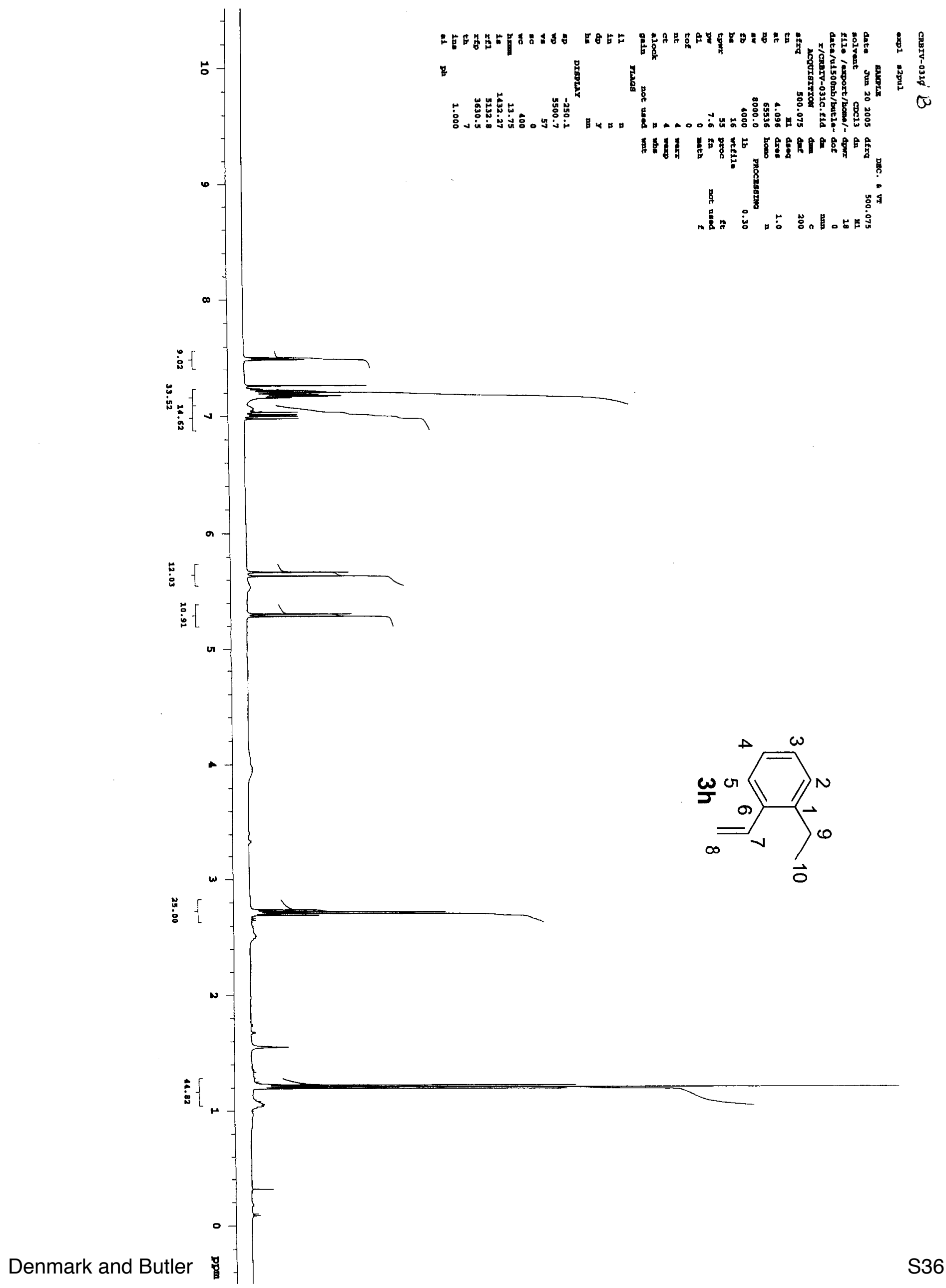




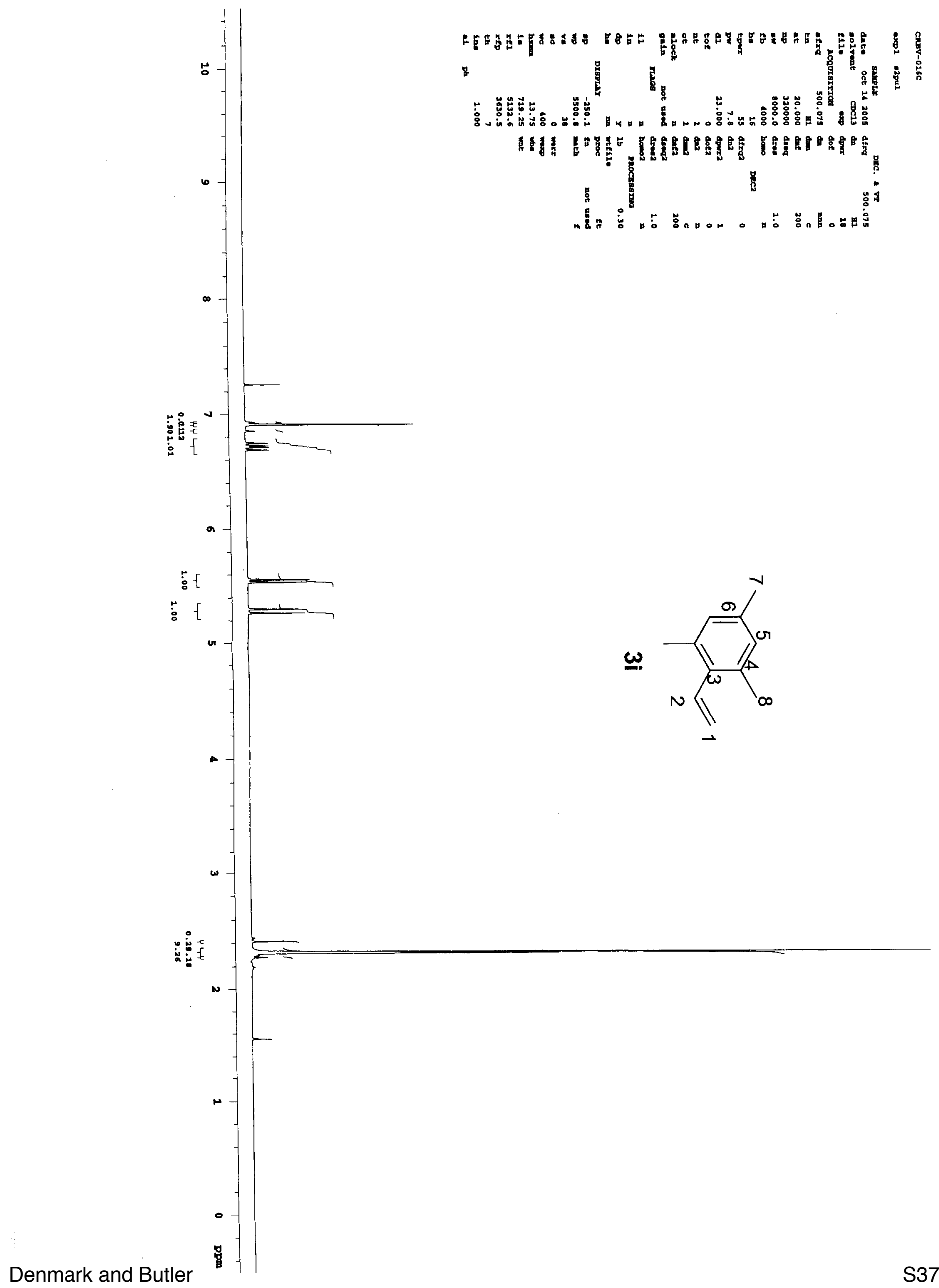




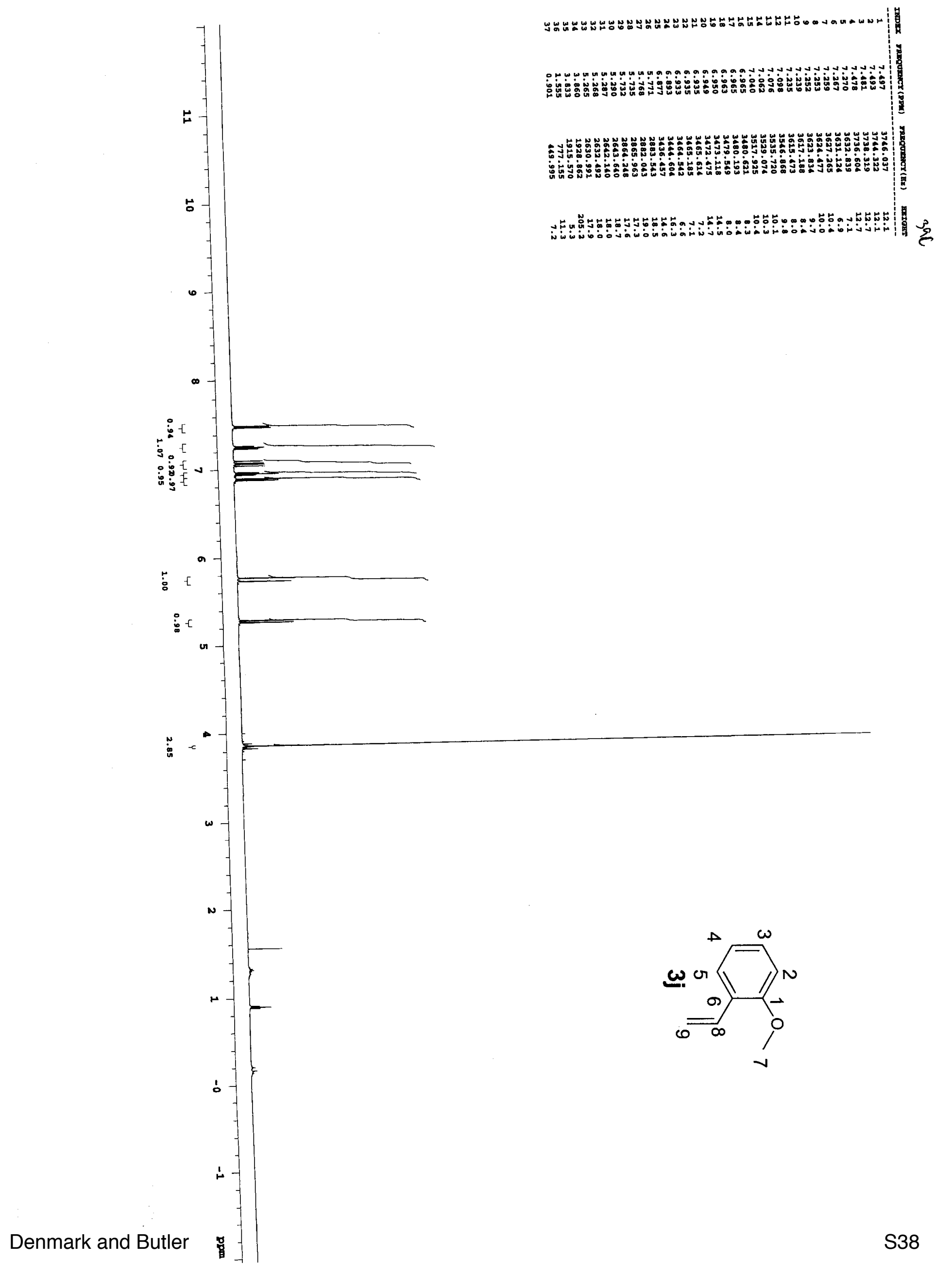




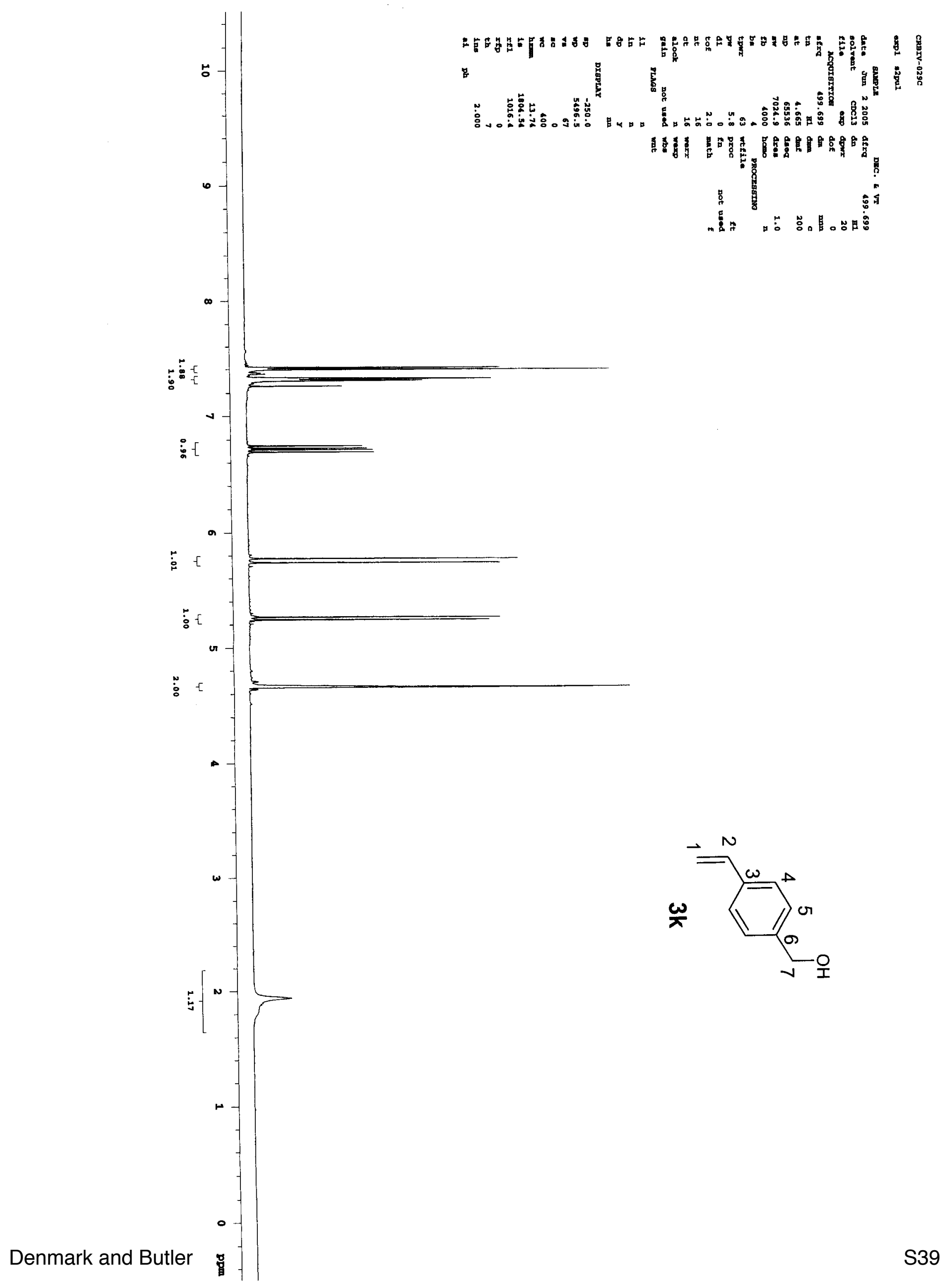




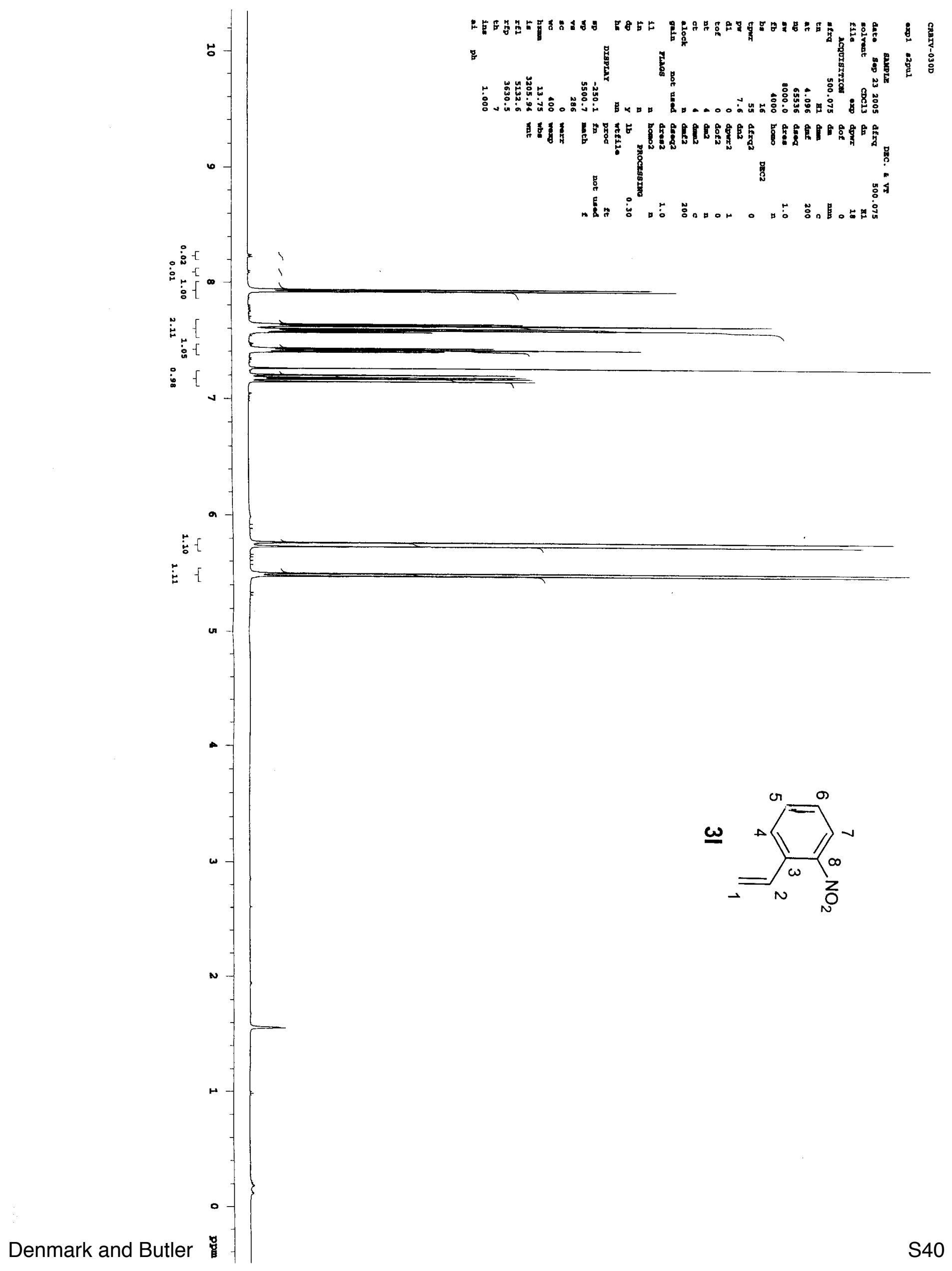




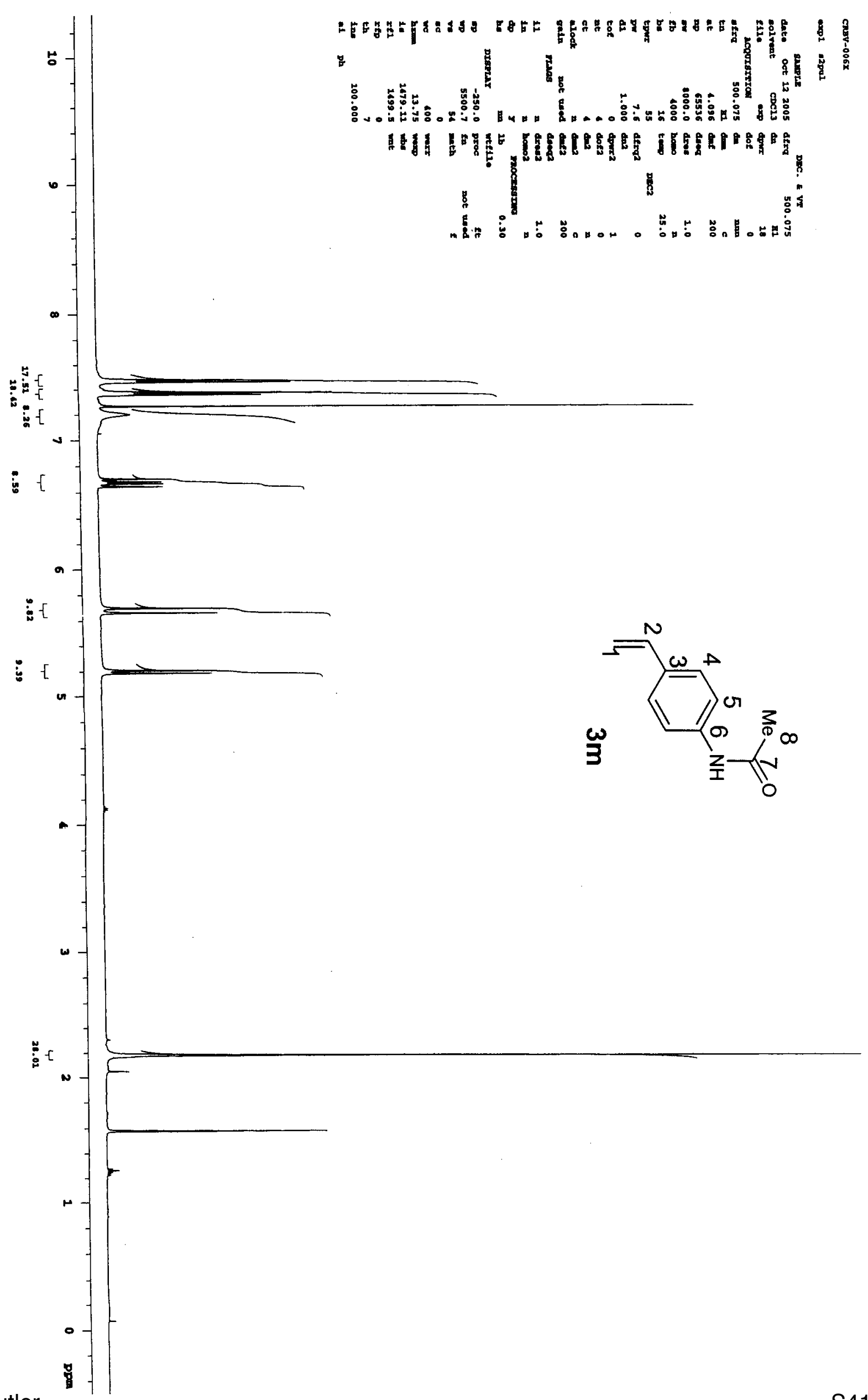




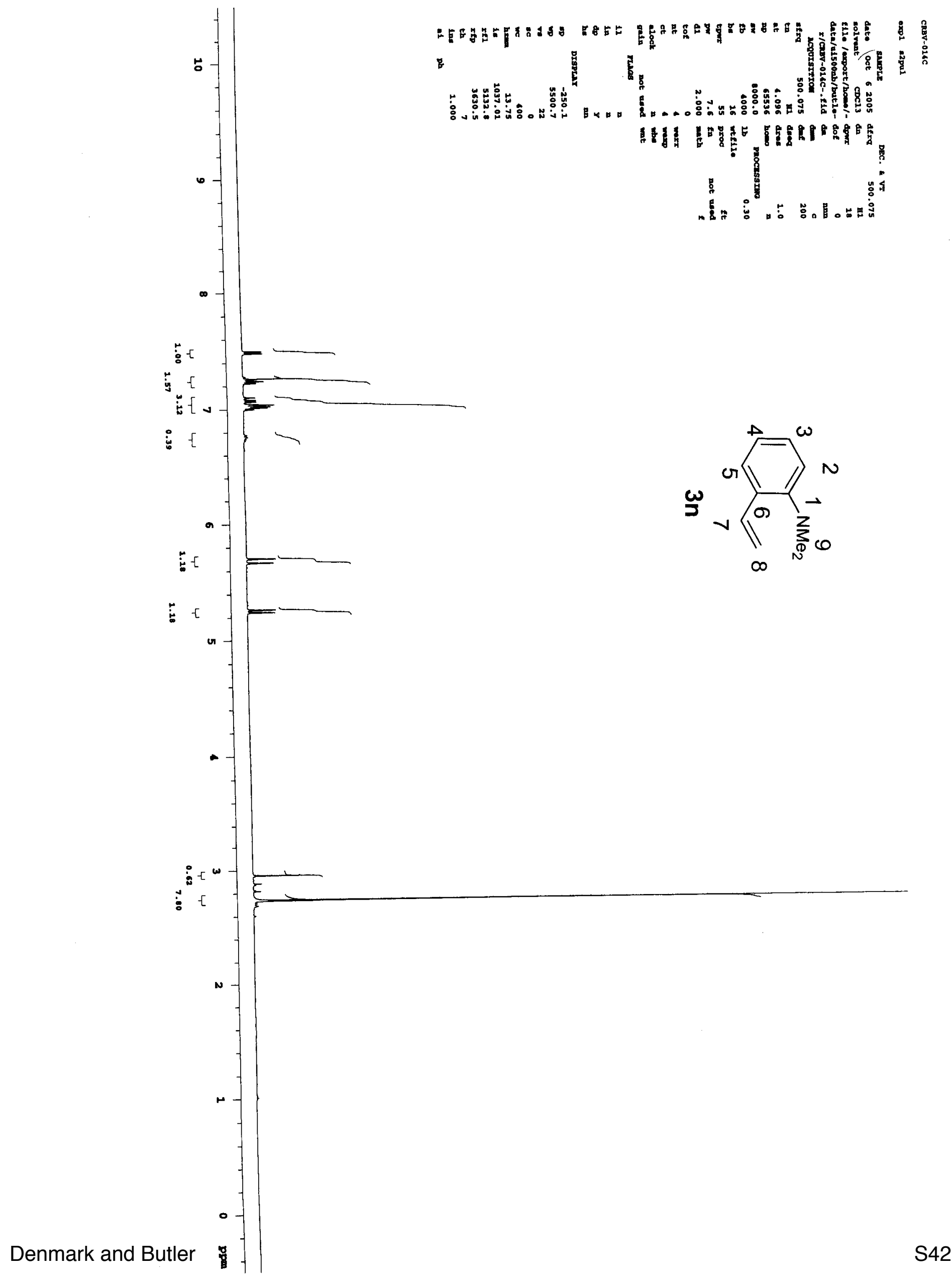




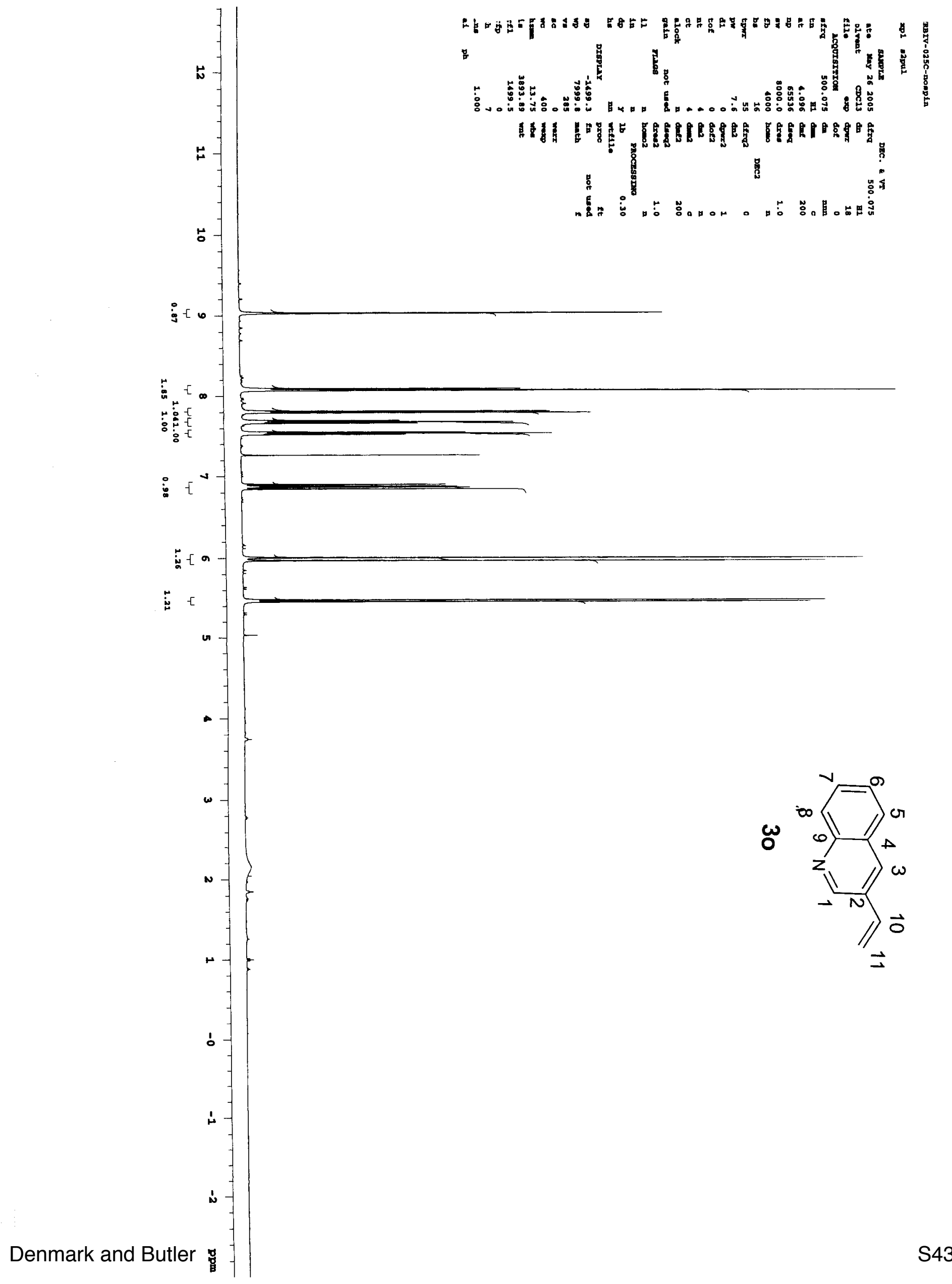

